Published in "Earth-Science Reviews 176 (): 195-213, 2018"

which should be cited to refer to this work.

\title{
Rapid decline of snow and ice in the tropical Andes - Impacts, uncertainties and challenges ahead
}

\author{
Mathias Vuille $^{\mathrm{a}, *}$, Mark Carey ${ }^{\mathrm{b}}$, Christian Huggel ${ }^{\mathrm{c}}$, Wouter Buytaert ${ }^{\mathrm{d}}$, Antoine Rabatel ${ }^{\mathrm{e}}$, \\ Dean Jacobsen ${ }^{\mathrm{f}}$, Alvaro Soruco ${ }^{\mathrm{g}}$, Marcos Villacis ${ }^{\mathrm{h}}$, Christian Yarleque ${ }^{\mathrm{a}}$, Oliver Elison Timm ${ }^{\mathrm{a}}$, \\ Thomas Condom ${ }^{\mathrm{e}}$, Nadine Salzmann ${ }^{\mathrm{c}, \mathrm{i}}$, Jean-Emmanuel Sicart ${ }^{\mathrm{e}}$
}

a Dept. of Atmospheric \& Environmental Sciences, Univ. at Albany, Albany, NY, USA

b Robert D. Clark Honors College, University of Oregon, Eugene, OR, USA

${ }^{c}$ Dept. of Geography, Univ. of Zurich, Switzerland

d Dept. of Civil and Environmental Engineering, Imperial College London, London, UK

e Univ. Grenoble Alpes, CNRS, IRD, Institut des Géosciences de l'Environnement (IGE), Grenoble, France

${ }^{\mathrm{f}}$ Freshwater Biological Laboratory, Dept. of Biology, University of Copenhagen, Copenhagen, Denmark

${ }^{\mathrm{g}}$ Instituto de Investigaciones Geológicas y del Medio Ambiente, Universidad Mayor de San Andres, La Paz, Bolivia

h Depto. de Ingenieria Civil y Ambiental, Escuela Politecnica Nacional, Quito, Ecuador

${ }^{i}$ Dept. of Geosciences, Univ. of Fribourg, Switzerland

Glaciers in the tropical Andes have been retreating for the past several decades, leading to a temporary increase in dry season water supply downstream. Projected future glacier shrinkage, however, will lead to a long-term reduction in dry season river discharge from glacierized catchments. This glacier retreat is closely related to the observed increase in high-elevation, surface air temperature in the region. Future projections using a simple freezing level height- equilibrium-line altitude scaling approach suggest that glaciers in the inner tropics, such as Antizana in Ecuador, may be most vulnerable to future warming while glaciers in the more arid outer tropics, such as Zongo in Bolivia, may persist, albeit in a smaller size, throughout the 21st century regardless of emission scenario. Nonetheless many uncertainties persist, most notably problems with accurate snowfall measurements in the glacier accumulation zone, uncertainties in establishing accurate thickness measurements on glaciers, unknown future changes associated with local-scale circulation and cloud cover affecting glacier energy balance, the role of aerosols and in particular black carbon deposition on Andean glaciers, and the role of groundwater and aquifers interacting with glacier meltwater.

The reduction in water supply for export-oriented agriculture, mining, hydropower production and human consumption are the most commonly discussed concerns associated with glacier retreat, but many other aspects including glacial hazards, tourism and recreation, and ecosystem integrity are also affected by glacier retreat. Social and political problems surrounding water allocation for subsistence farming have led to conflicts due to lack of adequate water governance. Local water management practices in many regions reflect cultural belief systems, perceptions and spiritual values and glacier retreat in some places is seen as a threat to these local livelihoods.

Comprehensive adaptation strategies, if they are to be successful, therefore need to consider science, policy, culture and practice, and involve local populations. Planning needs to be based not only on future scenarios derived from physically-based numerical models, but must also consider societal needs, economic agendas, political conflicts, socioeconomic inequality and cultural values. This review elaborates on the need for adaptation as well as the challenges and constraints many adaptation projects are faced with, and lays out future directions where opportunities exist to develop successful, culturally acceptable and sustainable adaptation strategies.

\footnotetext{
* Corresponding author at: Department of Atmospheric and Environmental Sciences, University at Albany, SUNY, 1400 Washington Ave., Albany, NY 12222, USA.
} E-mail address: mvuille@albany.edu (M. Vuille). 


\section{Introduction}

Glaciers in the tropical Andes have been retreating rapidly during the past decades, thereby temporarily increasing water supply in dry regions downstream. Yet this increase is not sustainable, as glaciers continue to shrink. Hence glacier retreat poses a significant challenge for adaptation of a variety of natural and human systems throughout the region. Almost all (> 99\%, Kaser, 1999) of the remaining glaciers in the tropics are located in the Andes; hence the situation in this region is of particular relevance. Glaciers are also very helpful visual indicators of our rapidly changing environment and can serve as sentinels of rapid climate change. This is especially the case for tropical glaciers, which are considered highly sensitive to changes in climate (Kaser and Osmaston, 2002).

Glacier retreat in the tropical Andes is of particular concern for a variety of reasons. First, unlike mid- and high-latitude mountain regions, there is no seasonal snow cover outside the glacierized areas, which could provide for an additional buffer and contribution to seasonal river discharge. Because of the high solar radiation all year long, snow falling outside of glacierized areas melts within a matter of a few days (Lejeune et al., 2007; Wagnon et al., 2009). While this snowmelt may contribute to immediate river discharge or potentially to groundwater recharge, it prevents the build-up of a seasonal snowpack that can provide water at the beginning of the dry season. Secondly, the southern tropical Andes (central and southern Peru and Bolivia) experience a long and sustained dry season that lasts between five and six months from April until September (Garreaud et al., 2003). During this period rainfall is virtually absent and the glacier meltwater contribution is fundamentally important for socioeconomic activities and environmental services, especially those that take place in close proximity to the glacierized catchments (Barnett et al., 2005; Bradley et al., 2006; Kaser et al., 2010). This is why glacier retreat is much more of a concern in the semiarid southern tropical Andes, at least from a water supply perspective.

The northern tropical Andes (Colombia, Venezuela and Ecuador) experience a much more humid climate with shorter dry periods and some rainfall throughout the year. In addition, glaciers are generally smaller in this region, and wetland ecosystems called páramos, can provide for additional water storage, as their soils have a very high water retention capacity (Buytaert et al., 2006, 2011). Nonetheless, even in Ecuador glacier melt can temporarily provide for a significant base flow that can become relevant during extreme drought periods (Sicart et al., 2015).

The spatial extent and pace of Andean glacier retreat have been documented in numerous studies, including two fairly recent in-depth reviews (Vuille et al., 2008a; Rabatel et al., 2013). Similarly, the largescale drivers of this retreat, such as increasing temperature (Vuille and Bradley, 2000; Bradley et al., 2009; Schauwecker et al., 2014; Vuille et al., 2015) or potential changes in the spatiotemporal characteristics of snowfall (Vuille and Ammann, 1997; Mernild et al., 2016; Saavedra et al., 2016), thereby altering the glacier's energy and mass balance, have been widely studied and discussed. Hence the goal of this paper is not to provide yet another detailed review of these observed changes, but rather to look ahead as to what impacts the region will face over the coming decades as glaciers continue to retreat and some eventually disappear.

While much emphasis in recent years has been put on better understanding the supply side of water resources through glacio-hydrologic modeling under a variety of future scenarios, there is an increasing recognition that much of the future water scarcity and struggles over allocation and access to clean water may be driven primarily by the demand side (Carey et al., 2017). Indeed in wide regions of the tropical Andes water scarcity will increase regardless of climate change scenario, speed and magnitude of glacier retreat (Buytaert and de Bievre, 2012). It is therefore indispensable to include socioeconomic, cultural, legal and political aspects of water use and regulations at all stages of future socio-hydrologic modeling attempts (e.g. Carey et al., 2014). In addition glacier retreat increases the potential for natural hazards, affects ecosystem composition in rivers downstream and may impact economic sectors such as tourism or mining. Social values, local perceptions and cultural beliefs are also closely intertwined with water use and the existence of glaciers in the region. The major aim of this review is thus to identify how glacier retreat affects Andean natural and human systems today and to identify major gaps and roadblocks for current adaptation efforts. A special emphasis will be put on the challenges that loom going forward, as Andean nations start implementing adaption measures to address these impacts, in the light of large uncertainties associated with future climate projections. Thereby we hope to contribute to the discussion surrounding the major challenges but also potential opportunities for climate change adaptation in the region today.

\section{Current state of glaciers and climate change in the tropical Andes}

Two recent comprehensive reviews on the current state of Andean glaciers and their response to climate change were published by Vuille et al. (2008a) and Rabatel et al. (2013). Both studies picture a situation characterized by a rapidly shrinking surface area, length and volume of glaciers due to an almost continuously negative mass balance, particularly since the late 1970s. Superimposed on the negative trends are variations on interannual and decadal time scales, that primarily reflect the state of tropical Pacific sea surface temperatures (SST), with often (but not always) significant mass loss during warm episodes associated with El Niño events, while cold phases (La Niña) tend to lead to less negative or in some cases even balanced or slightly positive mass balance (e.g., Francou et al., 2003, 2004; Vuille et al., 2008b; Favier et al., 2004; Lopez-Moreno et al., 2014; Veettil et al., 2014). Wagnon et al. (2001) and more recently Maussion et al. (2015) examined the role played by the El Niño - Southern Oscillation (ENSO) phenomenon in more detail and quantified the various energy fluxes that contribute to ENSO-related mass balance anomalies on glaciers in the Cordillera Real, Bolivia, and Cordillera Blanca, Peru (see Fig. 1), respectively. They confirmed that the influence of El Niño is transmitted primarily through reduced and delayed snow accumulation and increased air temperature, causing an elevated rain-snow line, lowered albedo and therefore increased absorption of short-wave radiation. The higher temperature also leads to an increased sensible heat flux, while the precipitation deficit during most El Niño events contributes directly to a more negative mass balance (reduced snow accumulation and albedo effect (Wagnon et al., 2001; Sicart et al., 2011)).

While ENSO events lead to significant interannual variability of Andean glaciers' energy and mass balance, the long-term negative trend cannot be pinned on tropical Pacific SST's (Vuille et al., 2015). In fact paleoclimatic studies show that throughout the Andes, glaciers have been retreating for a long period of time. They reached a relative maximum extent sometime during the Little Ice Age (LIA) between the middle of the 17th and the beginning of the 18th century, likely associated with cooler and wetter conditions. The exact timing of this advance however, varies somewhat depending on the mountain range considered (Rabatel et al., 2006, 2008; Solomina et al., 2007; Jomelli et al., 2009). But in most locations glaciers have been receding ever since, except for a few intermittent periods of glacier stabilization or even mass gain, such as occurred for example in the mid 1960s to early 1970s in the Cordillera Real. According to Rabatel et al. (2013), the retreat has accelerated over the past three decades, with an average mass loss in the tropical Andes estimated at $-0.76 \mathrm{~m}$ water equivalent (w.e.) over the period 1976-2010. This suggests that glaciers in the tropical Andes are characterized by a more negative mass balance than the average glacier monitored in the rest of the world (see Fig. 7 in Rabatel et al., 2013). Glaciers located entirely below $5400 \mathrm{~m}$ above sea level (a.s.l.) are generally small $\left(<1 \mathrm{~km}^{2}\right)$ compared to high-altitude 


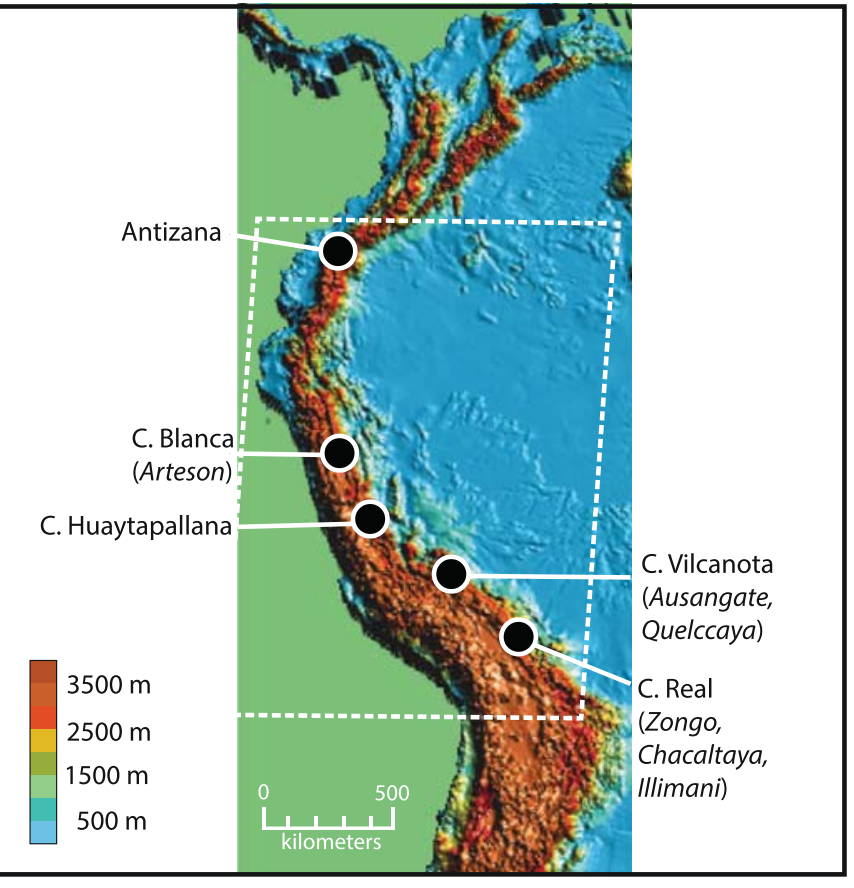

- Fig. 1. Map of the tropical Andes, with locations of glaciers and mountain ranges discussed in the text. White box $\left(2^{\circ} \mathrm{N}-18^{\circ} \mathrm{S} / 65^{\circ}-82^{\circ} \mathrm{W}\right)$ indicates area over which CMIP 5 models were averaged to derive simulated historical and projected temperature change over the Andes.

glaciers and experience an even more negative mass balance and more rapid decline. Indeed these glaciers in their majority appear to be very unbalanced (negative mass balance of $-1.2 \mathrm{~m}$ w.e. over the past 3 decades, compared to $-0.6 \mathrm{~m}$ w.e. for glaciers that extend above $5400 \mathrm{~m}$ a.s.1.), with many of them likely to disappear in the coming decades (Rabatel et al., 2013). It is noteworthy that these glaciers represent the majority of all glaciers in the tropical Andes (e.g. 80\% in the Bolivian Cordillera Real in 1975), corresponding to half of the glacierized surface area (Soruco et al., 2009). Overall the current rate of glacier loss appears to be unprecedented for the period over which reasonably accurate reconstructions exist (since the early 18th century).

Since the publication of Rabatel et al. (2013) a few new studies focusing on specific mountain ranges have been published, which all essentially confirm the results described above. Braun and Bezada (2013) for example have documented in great detail the rapid shrinkage and looming disappearance of tropical glaciers from the Andes in Venezuela. Hanshaw and Bookhagen (2014) and Lopez-Moreno et al. (2014), based on a long series of satellite images, highlighted the rapid shrinkage of glaciers in the Cordillera Vilcanota and Huaytapallana, respectively. Both studies identified significant and fast glacier retreat with a $>50 \%$ surface area loss in the Cordillera Huaytapallana between 1984 and 2011 and a roughly 25\% area loss in the Cordillera Vilcanota between 1962 and 2009.

These observed changes in glacier extent in the tropical Andes are consistent with observations of temperature and precipitation changes in the Andes during this same time period. A number of studies have presented evidence for a rapidly changing climate in the tropical Andes. Vuille and Bradley (2000) first documented a clear warming trend over the Andes in the 20th century (based on a large number of in-situ station data), covering the tropical Andes from Ecuador to northern Chile. They also identified, for the first time, that the observed warming appeared to be dependent on elevation and slope. Follow-up studies by Vuille et al. (2003, 2008a) documented a warming of roughly $0.1{ }^{\circ} \mathrm{C}$ per decade since the 1950s, when averaged over the entire tropical Andes south of the equator. These results are consistent with more regional temperature trend analyses performed later by Racoviteanu et al.
(2008), Poveda and Pineda (2009), Bradley et al. (2009), Gilbert et al. (2010), Lavado Casimiro et al. (2013), Salzmann et al. (2013), Seiler et al. (2013a) and Lopez-Moreno et al. (2014, 2016) in various locations of the Andes. More recently Schauwecker et al. (2014) and Vuille et al. (2015) analyzed the apparent slowdown of the warming, which may have been linked with the cooling observed over the eastern tropical Pacific and the cool phase of the Pacific Decadal Oscillation (PDO) since the early 2000s. According to these studies, however, the Pacific cooling affected primarily low-level coastal locations along the Pacific shore, while the highest elevations in the tropical Andes have continued to warm during this 'hiatus' period. In fact, as documented by Vuille et al. (2015), the warming at higher elevation in the tropical Andes now appears to have emerged outside the range of natural variability, effectively decoupling Andean temperature from the SST forcing in the Pacific, which in previous decades served as a strong predictor for cold or warm periods in the Andes.

Precipitation trends on the other hand are much more subtle and difficult to identify, partly due to the paucity of long, high-quality observational records and partly due to the strong modulation of precipitation by topography, introducing significant east-west gradients between the arid Pacific coast and the humid Amazon basin, thereby rendering precipitation trends inherently more heterogeneous. Vuille et al. (2003) initially suggested a tendency toward slightly increased precipitation in the inner tropics (north of $11^{\circ} \mathrm{S}$ ) and a decrease in the outer tropical Andes further south, although they emphasized that trends at individual stations were mostly insignificant. These results were later confirmed in a follow-up study by Haylock et al. (2006), identifying the same north-south contrast in precipitation trends. More recently Salzmann et al. (2013) and Lavado Casimiro et al. (2013) analyzed rainfall trends in the southern Peruvian Andes with newer and denser data sets and were unable to find significant trends over the past 40 years. Instead most of the variability in the data appears to be associated with interannual variability driven by the ENSO phenomenon (Rau et al., 2016).

In summary all these studies strongly link the observed glacier retreat to an increase in temperature - as the diverging and mostly insignificant trends in precipitation seem inconsistent with the coherent and strong glacier retreat observed throughout the tropical Andes region. We wish to stress, however, that estimating snowfall totals in the accumulation zone of Andean glaciers is associated with large uncertainties (see Section 4.1) and that past changes in snow accumulation in the highest reaches of the tropical Andes are virtually unknown, except for a few point-estimates based on ice-core studies (see review in Vimeux et al., 2009). In addition, tropical glacier energy balance of course strongly depends on the seasonal distribution of precipitation. This distribution can change without being reflected in annual snowfall totals and may also affect seasonal temperature trends, for example through a delay of the wet season and reduced cloud cover.

\section{Challenges for future projections - where are we headed?}

\subsection{Climate projections}

Studies invoking future temperature projections in the Andes are quite limited and have focused primarily on free-tropospheric temperature. Bradley et al. (2004, 2006) were the first to consider future changes in free-tropospheric temperature along the Andes Cordillera by employing a multi-model ensemble from the Coupled Model Intercomparison Project Phase $2+(\mathrm{CMIP} 2+)$ and 3 (CMIP3) under a $2 \times \mathrm{CO}_{2}$ and the Intergovernmental Panel on Climate Change (IPCC) Special Report on Emission Scenarios (SRES) A2 scenario, respectively. According to their results, by the end of the 21st century the peak elevations of the tropical Andes might warm by up to $4^{\circ}-5{ }^{\circ} \mathrm{C}$ when compared to the base period (1990-1999) under a high emission scenario. The authors in these studies also pointed out that the models consistently simulated an amplified warming at higher elevations, 
although they did not diagnose or quantify the feedbacks involved in this elevation-dependent warming. Urrutia and Vuille (2009) subsequently employed a regional climate model to simulate both near-surface and free-tropospheric temperature change by the end of the 21st century, compared to the 1961-90 average, based on the SRES B2 and A2 scenarios. Their results also indicated that the warming would be amplified at higher elevations going forward, reaching up to $5-6{ }^{\circ} \mathrm{C}$ at the highest elevations in the $\mathrm{A} 2$ scenario and about half that amount in the lower emissions scenario B2. Urrutia and Vuille (2009) further pointed out that not only will temperature increase, but the interannual variability will also be considerably enhanced, especially in the A2 scenario, leading to a higher probability of extremely warm years. Their study, however, was based on only one climate model, which, as shown by Buytaert et al. (2010), can lead to large uncertainties in the interpretation, as ideally an ensemble of regional climate models should be used for such numerical downscaling applications. Thibeault et al. (2010) took a different approach by focusing on future projections of temperature extremes, such as heat waves, warm nights or frost days on the Bolivian Altiplano as simulated by an ensemble of CMIP3 models in the SRES B1, A1B and A2 scenarios. According to their results, frost days are projected to decrease by 2-4 standard deviations in all scenarios by the end of the 21 st century when compared to the reference year 2000, while warm nights and heat waves will become more frequent by 3-7 standard deviations (warm nights) and 1-4 standard deviations (heat waves) respectively, by the year 2100 . More recently Seiler et al. (2013b) analyzed both CMIP3 and CMIP5 models over Bolivia to estimate future temperature changes under a range of emission scenarios. According to their results, temperature in Bolivia will increase anywhere from $2.5^{\circ} \mathrm{C}$ to $6{ }^{\circ} \mathrm{C}$ by the end of the century compared to the 1961-90 period, depending on model and emission scenario considered.

Here we use seven CMIP5 models (HadGEM2-AO, HadGEM2-CC, HadGEM2-ES, MIROC-ESM-CHEM, MPI-ESM-LR, MPI-ESM-MR and NorESM1-ME, see Table 1) to analyze how surface temperature might evolve throughout the 21st century in the tropical Andes. We calculate anomalies with respect to the 1961-1990 reference period and analyze results from a moderate (Representative Concentration Pathway, RCP 4.5) and a high-emission (RCP 8.5) scenario to probe future outcomes. In order to compare future projections with past temperature trends we average the model data over a box $\left(2^{\circ} \mathrm{N}-18^{\circ} \mathrm{S} / 65^{\circ}-82^{\circ} \mathrm{W}\right.$, see Fig. 1$)$ that approximates the station coverage used for the recent Andean temperature re-assessment in Vuille et al. (2015) and we also analyze temperature trends in historical CMIP5 simulations of the same seven models since 1950. For each simulation we select one ensemble member per model.

Results of our analyses are shown in Fig. 2. They suggest that temperature in the tropical Andes might continue to increase by $1^{\circ}-5^{\circ} \mathrm{C}$

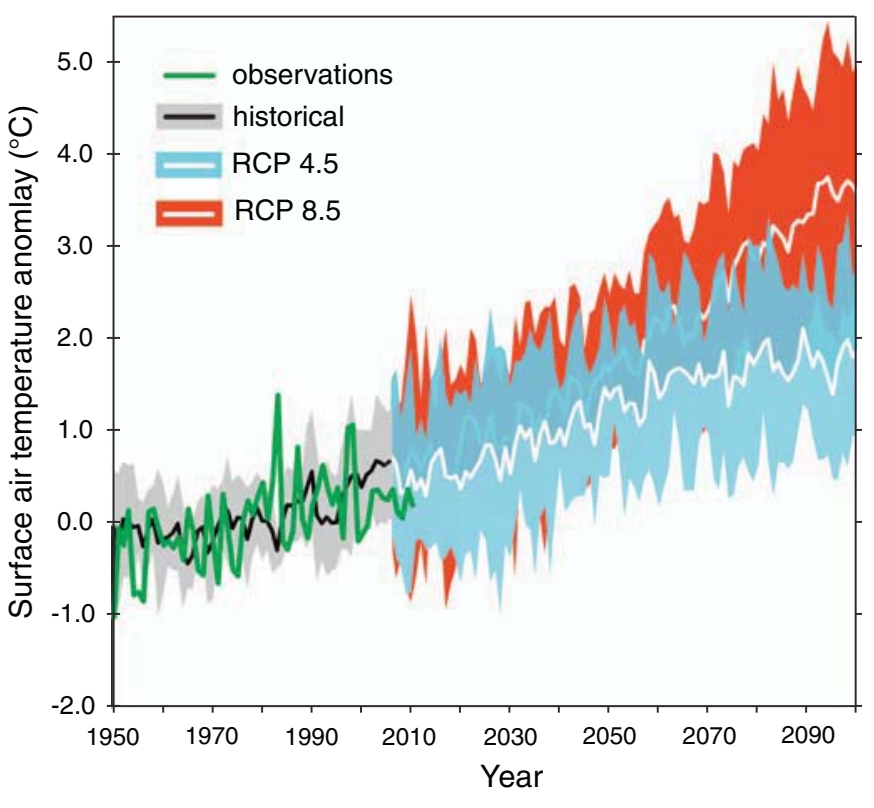

Fig. 2. Simulated and observed annual mean air temperature anomalies in the tropical Andes (departures from 1961 to 1990 mean) derived from station data (Vuille et al., 2015, green, 1950-2010), historical CMIP5 (gray, 1950-2005), and future CMIP5 scenarios (RCP 4.5 in light blue and RCP 8.5 in red, 2006-2100). CMIP5 data averaged over box $2^{\circ} \mathrm{N}-18^{\circ} \mathrm{S}, 65-82^{\circ} \mathrm{W}$ to match distribution of station data in Vuille et al. (2015). Shading indicates \pm 1.64 std. dev. (5-95\% range across models). (For interpretation of the references to colour in this figure legend, the reader is referred to the web version of this article.)

(mean values of $2^{\circ}-3.5^{\circ} \mathrm{C}$ ) beyond the $1961-90$ values. This warming is less than what was reported previously in some of the studies discussed above, but it should be kept in mind that these are surface and not freetropospheric trends and that they represent a large-scale average over a model topography that is significantly lower than reality. Hence surface warming is likely to be larger than these values reported here at high elevations where glaciers are located (see Vuille et al., 2015). Temperature trends associated with rising freezing levels and implications for the rise of the equilibrium-line altitude (ELA) of tropical Andean glaciers are analyzed separately in Section 3.2. It is noteworthy that the trend in the simulated warming over the historical period (1950-2005) is consistent with the observed warming by Vuille et al. (2015). But of course averaging over multiple models tends to reduce the interannual variability when compared with the observational record, as interannual signals related to internal variability (e.g. ENSO) are not in phase between models.

Several studies have tried to constrain future precipitation

Table 1

CMIP5 Models used in analysis of surface temperature and/or freezing level height.

\begin{tabular}{|c|c|c|}
\hline Modeling center & Institute ID & Model name \\
\hline Beijing Climate Center, China Meteorological Administration & BCC & BCC- CSM1.1(m) \\
\hline College of Global Change and Earth System Science, Beijing Normal University & GCESS & BNU-ESM \\
\hline Canadian Centre for Climate Modeling and Analysis & CCCMA & CanESM2 \\
\hline National Center for Atmospheric Research & NCAR & CCSM4 \\
\hline Community Earth System Model Contributors & NSF-DOE-NCAR & CESM1(BGC) \\
\hline Commonwealth Scientific and Industrial Research Organization in collaboration with Queensland Climate Change Centre of Excellence & CSIRO-QCCCE & CSIRO-Mk3.6.0 \\
\hline The First Institute of Oceanography, SOA, China & FIO & FIO-ESM \\
\hline National Institute of Meteorological Research/Korea Meteorological Administration & NIMR/KMA & HadGEM2-AO \\
\hline Met Office Hadley Centre & МOHC & $\begin{array}{l}\text { HadGEM2-CC } \\
\text { HadGEM2-ES }\end{array}$ \\
\hline $\begin{array}{l}\text { Japan Agency for Marine - Earth Science and Technology, Atmosphere and Ocean Research Institute (The University of Tokyo), and } \\
\text { National Institute for Environmental Studies }\end{array}$ & MIROC & MIROC-ESM-CHEM \\
\hline Max Planck Institute for Meteorology & MPI-M & $\begin{array}{l}\text { MPI-ESM-LR } \\
\text { MPI-ESM-MR }\end{array}$ \\
\hline Norwegian Climate Centre & NCC & NorESM1-ME \\
\hline
\end{tabular}


projections for the Andes, using a variety of different approaches. Most recently Neukom et al. (2015) were able to show that precipitation during the austral summer wet season (DJF) might drop below the range of natural variability in the central Andes of Bolivia and southern Peru within a matter of a few decades. Their analysis was based on a combination of proxy evidence from tree rings and ice cores since the year $1000 \mathrm{CE}$ with historical model runs and future Coupled Model Intercomparison Project Phase 5 (CMIP5)-based projections out to the year $2100 \mathrm{CE}$. These results are consistent with earlier findings by Urrutia and Vuille (2009), Minvielle and Garreaud (2011) and Thibeault et al. (2010, 2012) who used dynamical and statistical downscaling techniques, respectively, to determine future changes in precipitation, based on the older IPCC-SRES scenarios. While these projections of a roughly $10-30 \%$ decrease in precipitation by the end of the century appear to be quite robust, given that they have been reproduced by multiple studies employing different methodologies, the uncertainty regarding future precipitation changes is much larger in the more humid inner tropics. Buytaert et al. (2010) and more recently Zulkafli et al. (2016), for example, showed that in the Andes of Ecuador, models have difficulties in even agreeing on the sign of future changes in precipitation. Nevertheless, some studies suggest that the moisture flux from the Amazon basin to the Andes may weaken under a future warming-scenario (e.g. Marengo and Espinoza, 2016).

\subsection{Glaciologic projections}

For longer-term projections of future watershed hydrology a quantitative prediction as to how the glacier area and volume will change over time is essential (e.g. Frans et al., 2015). Ideally this requires a realistic simulation of dynamic glacier flow, which is still a challenge in hydro-glaciologic modeling. In addition the coupling between largescale climatic information, derived from historical simulations or future projections of climate change, and glaciologic and hydrologic models requires downscaling of the climate information to the catchment scale to bridge this scale mismatch. Some studies have circumvented this problem by general approximations of temperature focusing on the close coupling between the ELA of tropical glaciers and the $0{ }^{\circ} \mathrm{C}$ isotherm (the freezing level) (Condom et al., 2007; Rabatel et al., 2012; Sagredo et al., 2014), while others have exploited the relationship between freezing level height (FLH) and glacier extent (Schauwecker et al., 2017). As shown in Fig. 3, there is indeed a close relationship between FLH and glacier ELA in the tropical Andes on interannual time

b)

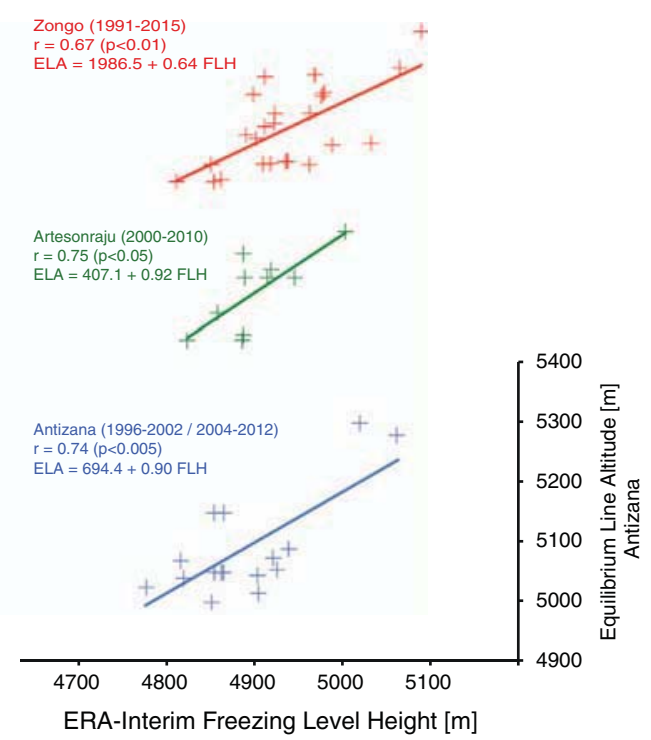

ERA-Interim Freezing Level Height [m] scales, consistent with previous reports (Vuille et al., 2008a; Bradley et al., 2009; Rabatel et al., 2013). In our analysis we focus on glaciers Antizana $\left(0^{\circ} 29^{\prime} \mathrm{S}, 78^{\circ} 09^{\prime} \mathrm{W}, 4780-5760 \mathrm{~m}\right.$, Ecuador), Artesonraju $\left(8^{\circ} 57^{\prime} \mathrm{S}, 77^{\circ} 27^{\prime} \mathrm{W}, 4685-5979 \mathrm{~m}\right.$, Peru) and Zongo $\left(16^{\circ} 15^{\prime} \mathrm{S}, 68^{\circ} 10^{\prime} \mathrm{W}\right.$, $4900-6000 \mathrm{~m}$, Bolivia), which have the longest mass balance time series available, and which allow us to probe a set of glaciers representative of inner and outer tropical sites (Fig. 1). The ELA data are based on measurements first published (and subsequently updated) in Rabatel et al. (2012), Loarte et al. (2015) and Basantes-Serrano et al. (2016).

Both ELA and FLH values were calculated based on averages over the hydrologic year. The Antizana mass balance value from 2003 was omitted from the analyses, as it was a large outlier, inconsistent with the relationship shown in Fig. 3. Indeed glacier mass balance estimates on Antizana are known to suffer from significant uncertainties due to difficulties in obtaining accurate measurements from the accumulation zone (Basantes-Serrano et al., 2016).

Schauwecker et al. (2014) have shown that significant differences exist between reanalysis products, when assessing free tropospheric temperature trends over the Andes, with NCEP/NCAR showing stronger warming at mid-tropospheric levels than ERA-Interim. Here we therefore probe these same two products in assessing trends in FLH and its relationships with the ELA in different mountain regions. The FLH was calculated by linearly interpolating temperature and geopotential height between 500 and $600 \mathrm{hPa}$ and then extracting geopotential height at the interpolated level where temperature equals $0{ }^{\circ} \mathrm{C}$. This was done separately for both reanalysis products and each location (grid cell covering glacier site).

Fig. 3 shows that the ELA is significantly correlated $(p<0.05)$ with FLH at all sites. Depending on reanalysis product, changes in FLH explain between roughly half and two thirds of the total variance in the ELA on Zongo, Artesonraju and Antizana, respectively. The slope of the relationship tends to be steeper in the inner tropics (Antizana) and become flatter toward the outer tropics (Zongo), consistent with the tendency of inner tropical glaciers to be more sensitive to direct temperature variations, while outer tropical glaciers, where the ELA is several hundred meters above the FLH, tend to be more strongly tied to changes in hydrologic variables (Favier et al., 2004). ERA slopes are steeper than those derived from NCEP/NCAR, but all slopes are significantly different from zero (F-test, $p<0.05$ ).

We next employed the relationships examined above to probe future changes in the ELA at these three glacier locations. We first calculated

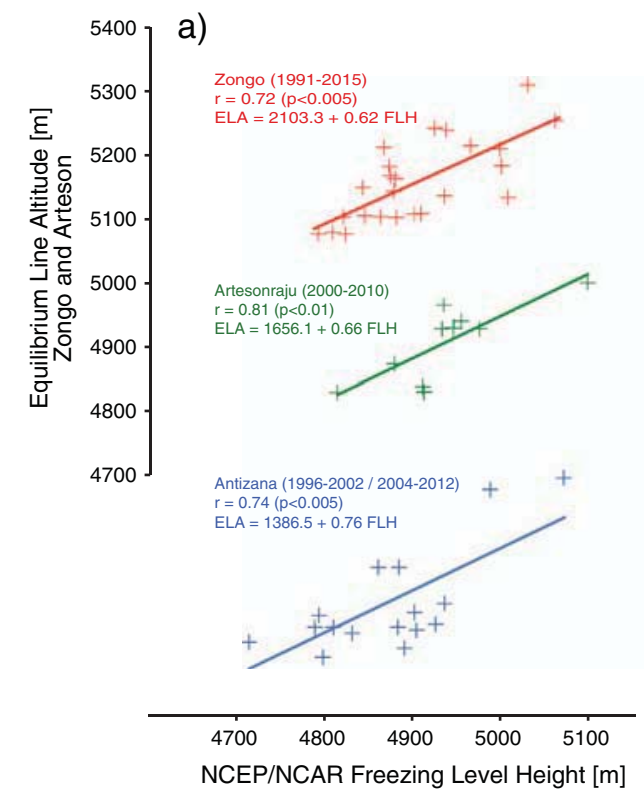

Fig. 3. Scatterplot and ordinary least squares linear regression of hydrologic year ELA vs. FLH on glaciers Zongo (Bolivia), Artesonraju (Peru) and Antizana (Ecuador). FLH is derived from a) NCEP/NCAR (Kalnay et al., 1996) and b) ERA-Interim (Dee et al., 2011). ELA data is from Rabatel et al. (2012), Loarte et al. (2015) and Basantes Serrano et al. (2016). 

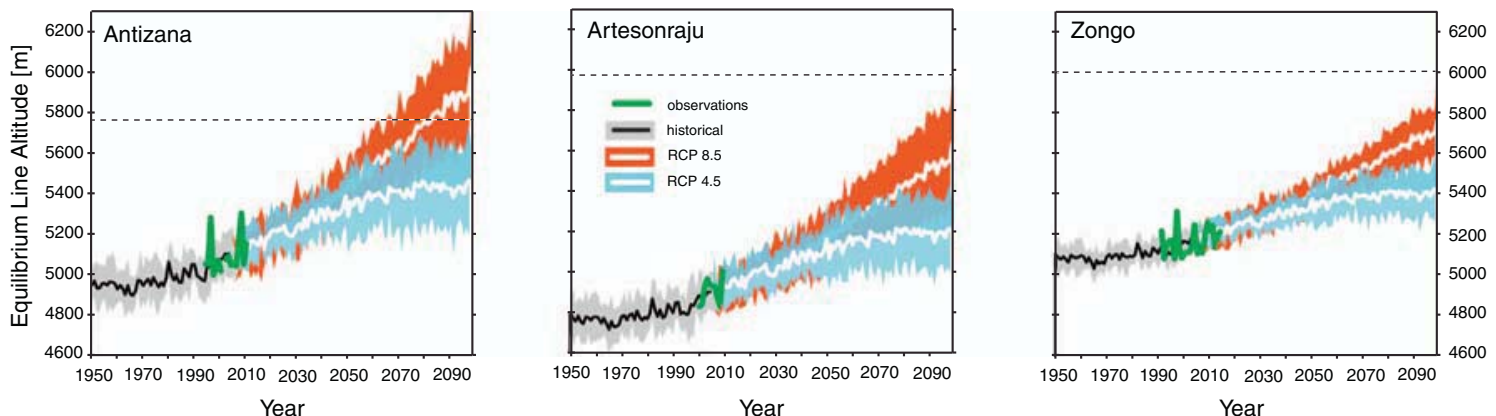

Fig. 4. Past, present and future hydrologic year mean ELA on Antizana, Artesonraju and Zongo glaciers, derived from observations (green), historical CMIP5 (gray), and future CMIP 5 scenarios (RCP 4.5 in light blue and RCP 8.5 in red). Observed ELA data is from Rabatel et al. (2012), Loarte et al. (2015) and Basantes Serrano et al. (2016). CMIP5 ELA's represent multimodel average, with shading indicating \pm 1.64 std. dev. (5-95\% range across models). Horizontal dotted black line indicates peak elevation of glacier according to Rabatel et al. (2013). (For interpretation of the references to colour in this figure legend, the reader is referred to the web version of this article.)

the FLH over the glacier sites based on geopotential height and temperature at $500 \mathrm{hPa}$ and $600 \mathrm{hPa}$ using one ensemble member each from eight different CMIP5 models (BCC-CSM1.1(m), BNU-ESM, CanESM2, CCSM4, CESM1(BGC), CSIRO-Mk3.6.0, FIO-ESM and HadGEM2-AO, see Table 1). We applied this methodology to CMIP5 historical simulations (1950-2005), a medium- and a high-emission scenario (RCP4.5 and RCP 8.5, 2006-2100). Next future changes in the ELA were calculated based on the simulated FLH in the eight models and applying both reanalysis-scaling methods, resulting in a total of 16 ELA trajectories for each scenario and glacier. Fig. 4 shows the resulting future mean ELA trajectory and the 5-95\% confidence intervals under both emission pathways as well as for the historical simulations. We also include the observed ELA reconstructions from Rabatel et al. (2012), Loarte et al. (2015) and Basantes-Serrano et al. (2016) for comparison. All model time series are corrected for biases in their calculated ELA, by adjusting their ELA to match observations for the reference year 2005 at the respective glacier sites. The average ELA bias for the period of overlap between observations and historical CMIP5 data is $53.8 \mathrm{~m}$ (Antizana), $-23.4 \mathrm{~m}$ (Artesonraju) and $-50.2 \mathrm{~m}$ (Zongo) when applying the NCEP/NCAR scaling and $50.7 \mathrm{~m}$ (Antizana), $-3.0 \mathrm{~m}$ (Artesonraju) and $-70.4 \mathrm{~m}$ (Zongo) when applying the ERAInterim scaling.

It is noteworthy that ERA-Interim and NCEP/NCAR show very similar trends in FLH (and hence ELA calculations) over the historical period and that the spread in the future model trajectories of the ELA is not caused by differences between ERA and NCEP scaling methods, but by CMIP5 intra-model differences (not shown). This may seem in contradiction to results by Schauwecker et al. (2014), which showed little warming at $500 \mathrm{hPa}$ in the ERA reanalysis when compared to NCEP/ NCAR. However, changes in FLH depend on changes in geopotential height as well; a variable, which indeed shows a significant upward trend at $500 \mathrm{hPa}$ in the ERA data over the Andes. In other words, while temperature at the $500 \mathrm{hPa}$ level may not have increased much, this temperature is being measured at an increasingly higher elevation, reflecting the overall warming of the tropical mid-troposphere. Hence interpreting temperature trends at fixed pressure levels can be misleading and should ideally be converted to absolute elevations above sea level.

The results in Fig. 4 suggest that the future rise of the ELA, as a result of an increase in FLH, will affect inner tropical sites such as Antizana the most. Based on our results Antizana glacier will likely be lost under a high emission scenario while a smaller glacier may be able to persist at the highest elevations under the RCP4.5 scenario. These results are consistent with the notion that inner tropical glaciers are more sensitive to changes in temperature, while outer tropical glaciers, such as Zongo, where the ELA is several hundred meters above the FLH, may be more strongly affected by future changes in the hydrologic cycle. Indeed our projections of the ELA rise suggest that both Zongo and Artesonraju glaciers may persist as smaller glaciers toward the end of the 21st century, with the ELA located between $\sim 5200 \mathrm{~m}$ a.s.l. (RCP4.5) and $\sim 5600 \mathrm{~m}$ a.s.l. (RCP8.5) on Artesonraju and between $\sim 5400 \mathrm{~m}$ a.s.l. (RCP4.5) and $\sim 5700 \mathrm{~m}$ a.s.l. (RCP8.5) on Zongo, respectively.

Our analysis is exploratory in nature and we are fully aware that it includes a number of assumptions, uncertainties and simplifications. As shown above, changes in FLH, while fundamentally important, do not explain all the variance in the ELA data. Many other factors also play a role, but were ignored in our analysis. For one, mass balance, and hence the ELA, is also a strong function of accumulation (snowfall). Our analysis implicitly assumes that the role played by snowfall will not change going forward, which may not be the case if seasonality or total snowfall amounts change. Future glacier retreat and hence ELA changes will also depend on the strength of local ice-albedo feedbacks, elevation feedbacks (glacier thinning will expose the glacier surface to higher temperatures at lower elevations regardless of future warming) and edge effects will enhance warm air advection. Given that projections suggest a decrease in future precipitation, at least in the outer tropics (Minvielle and Garreaud, 2011; Neukom et al., 2015) and the fact that all these positive feedbacks were ignored, our estimates likely err on the conservative side.

Regardless of these uncertainties, we consider this analysis a useful first step, as it allows for a fairly straightforward large-scale assessment of the future fate of glaciers in the region. More detailed analyses, which take into account changes in the hydrologic cycle, require fairly complex downscaling procedures. FLH, on the other hand, is a variable that can be derived directly from coarse global models and which is known to be closely related to glacier mass balance in the tropical Andes (Vuille et al., 2008a; Rabatel et al., 2013). Given the large spread between the two emission scenarios and the considerable uncertainty introduced by CMIP5 model differences, the errors incurred by our methodology are in all likelihood comparatively small.

There are a few studies that have attempted to make more realistic long-term projections of individual glacier volume and extent using a more sophisticated approach. Réveillet et al. (2015) for example used a 3-dimensional full-Stokes model called Elmer-Ice to simulate the evolution of Zongo glacier in the Cordillera Real, Bolivia, for both presentday and future conditions. Implicit in this modeling approach is the assumption that future temperature changes will directly affect the ELA, which is reasonable, given the close relationship between freezing level height and ELA shown above (Fig. 3). Changes in the ELA, on the other hand are directly related to the surface mass balance of the glacier. In this approach future glacier volume can be simulated as a dependence of future temperature change using CMIP5 model output, assuming that the general vertical mass balance profile remains the same, but will move upslope as a function of a higher ELA. Given that temperature is a more robust variable with much lower uncertainty bounds than for example precipitation, the modeling approach is considerably more straightforward. Based on estimates by Réveillet et al. 
(2015) Zongo glacier would lose $40 \%, 69 \%$ and $89 \%$ of its current ice volume by the end of the 21st century under the three emission scenarios RCP2.6, RCP6.0 and RCP8.5, respectively. However, this approach neglects any potential future changes in snowfall, which could also affect glacier mass balance. Given the general consensus of a future decrease in precipitation, as portrayed in Urrutia and Vuille (2009), Minvielle and Garreaud (2011) and more recently confirmed by Neukom et al. (2015), these projections by Réveillet et al. (2015) also have to be considered conservative estimates.

\subsection{Hydrologic (water supply-side) projections}

The impact of glaciers on the terrestrial water cycle is essentially two-fold: they may alter the catchment water balance, as well as the timing and variability of streamflow. The impact of glaciers on catchment runoff is typically considered to be positive because the combined evaporation and sublimation rate of the glacier surface tends to be lower than the evapotranspiration rates of other land-cover types. There is, however, still considerable uncertainty regarding actual sublimation rates and how they vary regionally, seasonally and along an altitudinal gradient. Average sublimation rates from tropical glaciers are commonly considered to be on the order of $0.5-1.0 \mathrm{~mm} \mathrm{~d}^{-1}$ (Hurley et al., 2016), although sublimation is highly seasonal, with higher values during the dry austral winter, when increased wind speed and the drier boundary layer tend to favor increased sublimation rates. Wagnon et al. (1999), for example, measured sublimation rates of $0.3 \mathrm{~mm} \mathrm{~d}^{-1}$ in October and $1.1 \mathrm{~mm} \mathrm{~d}^{-1}$ in July near the equilibrium line on a glacier in Bolivia. At much higher elevation, at $6340 \mathrm{~m}$ a.s.l., Wagnon et al. (2003) found values between 0.8 and $1.2 \mathrm{~mm} \mathrm{~d}^{-1}$ on Nevado Illimani in Bolivia. Winkler et al. (2009) reported significantly higher sublimation rates in the Andes of Peru, although these results still have to be confirmed at other sites. They performed a detailed study both measuring and modeling sublimation rates on glacier Artesonraju and found values as high as $1-5 \mathrm{~mm} \mathrm{~d}^{-1}$ during the dry season, although they confirmed that sublimation rates were much lower during the wet season.

Characterizing evapotranspiration from non-glacierized surfaces has equally been a challenge and studies are limited due to lack of meteorological data. Buytaert et al. (2007) and Córdova et al. (2015), suggested values between 1.8 and $2.0 \mathrm{~mm} \mathrm{~d}^{-1}$, but errors are thought to be as high as $30 \%$. Ochoa-Tocachi et al. (2016) calculated reference evapotranspiration in Andean catchments from Ecuador, Peru and Bolivia based on temperature data and obtained values ranging from 765 and $1374 \mathrm{~mm} \mathrm{a}^{-1}$, significantly more than what is lost through sublimation from glacierized surfaces.

A reduction of glacier cover will therefore reduce streamflow, because of increased evapotranspiration from newly ice-free areas (Frans et al., 2015). However, this effect tends to reduce quickly with catchment size and distance from the glacier terminus. In contrast the impact of glaciers on water availability through their seasonal buffering capacity of streamflow tends to be much larger and persist much further downstream (e.g. Mark and Seltzer, 2003; Juen et al., 2007). The magnitude of this effect is determined by the interaction between seasonal variations in precipitation and ablation. As a result, glaciers may provide a large relative contribution to dry season flow in regions with strong seasonality in precipitation (Mark and McKenzie, 2007; Soruco et al., 2015).

Accelerated glacier melt may further increase a glacier's contribution to river flow because of the glacier's negative mass balance (LaFreniere and Mark, 2014). But this effect is temporary and will decline with decreasing glacier size (Pouyaud et al., 2005). Eventually, streamflow seasonality will increase because of the reduced buffering capacity of the glacier. This effect, known as 'peak water' (Jansson et al., 2003) has been described by Baraer et al. (2012) for the Cordillera Blanca, Peru, where they suggested that glacial retreat initially leads to a water surplus in glacier-fed streams, but once a critical transition point is reached, dry season meltwater contribution will decline and eventually stabilize at a level that is $30 \%$ below the initial level (see also Pouyaud et al., 2005; Chevallier et al., 2011).

However, the impact on river discharge is scale-dependent and declines with downstream distance from the glacier. For instance, Soruco et al. (2015) did not detect a significant change in river discharge $(-0.6 \%$ in water production) from the glaciers in the Cordillera Real contributing to water supply of the city of La Paz, neither at annual nor seasonal time scales, despite a loss of approximately $43 \%$ of the glacierized area between 1963 and 2006. It is assumed that the increased melt rates essentially compensated the reduction in the surface area of the glaciers. Going forward, however, based on estimates by Soruco et al. (2015), the complete disappearance of these glaciers will lead to reduction in runoff of $12 \%$ annually, but $24 \%$ during the dry season. Note that the glacier discharge produced during the dry season $\left(4.3 \times 10^{6} \mathrm{~m}^{3} \mathrm{a}^{-1}\right)$ accounts for half of the water produced during the wet season $\left(8.4 \times 10^{6} \mathrm{~m}^{3} \mathrm{a}^{-1}\right)$ (Soruco et al., 2015). Uncertainties regarding future changes in precipitation, however, imply that substantial error bars belie these estimates.

In another study on Zongo glacier, Frans et al. (2015) applied a distributed glacio-hydrologic model to study the response of river discharge to future glacier retreat, with a simplified dynamic model using the shallow ice approximation approach. Their climate forcing data were obtained by downscaling reanalysis and CMIP5 model data using a stochastic weather generator. Their results indicate a decrease in annual and dry season discharge of 25 and $57 \%$ respectively by the end of the 21 st century, resulting from a loss of $81 \%$ of the glacier volume (in scenario RCP4.5, when compared to reference year 1987), which would render future glacier melt contribution negligible. This reduction is significantly more than the volume loss of only $69 \%$ in the higher emission scenario RCP6.0 found by Réveillet et al. (2015), highlighting the uncertainty in future projections of glacier loss associated with different methodologies, input parameters and assumptions concerning the different climate scenarios.

A more in-depth discussion and critical review of the various approaches linking climate with glacier and runoff modeling at various spatial and temporal scales in the Andes can be found in Fernandez and Mark (2016). A particularly noteworthy point raised in their review is the suggestion to perform glacio-hydrologic intercomparison studies at specific sites with good data coverage. Employing different modeling approaches (e.g. empirical temperature-index vs. physically-based energy balance models) over the same sites with the same data sets (to the extent that different approaches require the same input data) would allow for a much more detailed assessment of results and their specific model-dependence. Such experiments could potentially be integrated into the existing Glacier Modeling Intercomparison Project (GlacierMIP; http://www.climate-cryosphere.org/activities/targeted/glaciermip). The Zongo glacier in Bolivia or Antisana 15a glacier in Ecuador, which are among the best-equipped and monitored glaciers in the tropical Andes, would provide suitable targets for such an intercomparison study.

\subsection{Socio-economic (water demand side) projections}

While a considerable body of literature with focus on the water supply side (i.e. glacier retreat and its impact on meltwater availability downstream) has emerged over the past decade, there is an increasing realization that the water demand side may be an equally, if not more, important aspect of this equation (Bury et al., 2011; Drenkhan et al., 2015; Rasmussen, 2016; Carey et al., 2017). Buytaert and de Bievre (2012) for example analyzed future water supply and demand for four large cities in the Andes (Bogota, Quito, Lima, La Paz), of which one (La Paz) receives a significant water supply contribution from glacier melt, under a range of future scenarios. Their results suggest that future increases in water demand induced by demographic changes (population growth) will likely outpace any changes in water supply due to climate 
change, regardless of uncertainties in future growth scenarios. Hence they argue that population growth rather than a decline in water supply per se is the major driver of future water scarcity. They conclude that a stronger research and adaptation focus should be placed on the demand side, quantifying and regulating future water demand through adequate adaptation strategies, including water conservation, modern infrastructure to reduce water losses and policy instruments.

Indeed the increasing population, export-driven agricultural expansion, growth in water-intensive industries such as mining (Bebbington and Williams, 2008; Bebbington and Bury, 2009) and rising demand for electricity from hydropower plants (Finer and Jenkins, 2012) already cause water shortages (e.g., Boelens, 2014) in Peru, Bolivia, and Ecuador. As a result, trends in increasing water demand will continue and water shortages aggravate, regardless of the rate at which glaciers will retreat over the coming decades. To anticipate these issues and identify hotspots of water shortage and potential conflict, it is essential to understand the spatiotemporal patterns of water demand and how they interact with a changing supply. Within this context, political constellations as well as economic and marketdriven aspects will largely determine priorities for water allocation (Drenkhan et al., 2015). Water rights are distributed based on historical practices and trends, but also based on political conditions, economic agendas, institutional capacity, laws and legal structures, and cultural values. In the more rural areas of Peru and Bolivia in particular, access to adequate water systems and sanitation facilities for local populations is still insufficient. Hence improving this infrastructure is projected to further increase water demand close to glacierized headwaters (Carey et al., 2014). The same is true for agriculture that is reliant on irrigation. Large irrigation projects for export-oriented agriculture along the Peruvian coastal deserts (Chavimochic and Chinecas, for example) have led to a rapidly increasing water demand from the Rio Santa that drains the Cordillera Blanca (Bury et al., 2013; Carey et al., 2014; Drenkhan et al., 2015). In Peru subsistence farming based on crops such as alfalfa, barely or potatoes is increasingly being replaced by export crops (asparagus, rice, avocado) grown in these large coastal desert irrigation projects. But even in the more rural areas water demand for irrigation may increase. As pointed out by Hole et al. (2011) the rising temperatures may lead to an upward extension of the arable land, potentially further increasing the demand for water to be used in irrigation. In summary, multiple drivers affect current state and future trajectories of water demand. Clearly a much better characterization of current and future water demand will be necessary to complement glacio-hydrologic modeling of the supply side. Inevitably this will need to consider the socioeconomic, legal, political, ethical and cultural drivers that shape water demand in a watershed.

\section{New frontiers in Andean glacier and climate research}

While a lot of progress has been made in our understanding of tropical Andean glacier response to climate change in general, the sensitivity of glacier energy and mass balance to a number of specific natural and anthropogenic forcing terms is still poorly documented. Below we discuss some of these aspects in more detail and offer a few thoughts on why we believe these issues deserve special attention from the scientific community in the future.

\subsection{Revising in-situ mass balance estimates}

Most surface mass balance estimates in the tropical Andes are based on the glaciological method where routine measurements of ablation and accumulation are carried out based on a stake network. While measurements in the ablation zone are made once a month, measurements in the accumulation zone are logistically much more difficult and challenging and commonly only carried out once or twice a year. Obtaining reliable measurements in the zone that is representative of the entire upper reaches of glaciers is very challenging, given inaccessibility of certain areas with steep seracs and hidden crevasses, and the difficulty in determining a clear base of the annual accumulation layer, especially in the inner tropics, which lacks a clear dry season. The spatial extrapolation of such point measurements over the entire accumulation zone further enhances the uncertainties in the glacierwide mass balance, especially since the accumulation area tends to be larger than the ablation zone. On one of the most intensely surveyed glaciers, Antizana 15a, in the Andes of Ecuador, for example, $60 \%$ of the surface area is not covered by direct surface measurements. It may therefore not come as a big surprise that a reassessment of the mass balance of glacier Antizana 15a over the period 1995-2012 with geodetic measurements (mass change computed from digital elevation model differencing), suggests that the mass balance in the accumulation zone may have been significantly underestimated in previous studies (e.g. Francou et al., 2004). Based on the geodetic mass balance approach Basantes-Serrano et al. (2016) demonstrated that the accumulation totals above the ELA are approximately $70 \%$ higher than previously estimated with the glaciological method, resulting in a much reduced, less negative, overall mass balance of glacier Antizana 15a during the past two decades. To what extent these results simply reflect the particular precipitation characteristics of Antizana glacier, with a very steep vertical precipitation gradient, or whether they hint at a larger problem of accumulation measurements throughout the tropical Andes, remains an unanswered question.

An additional uncertainty regarding the representativeness of the Andean glacier network stems from the initial choice of glaciers that form part of this network. Because of the logistical challenges discussed above, the network established for long-term monitoring tends to be biased toward smaller glaciers, located at lower elevations, that are easier to access and safer to work on. It is well understood that such glaciers may be more prone to rapid glacier retreat and the first to completely disappear (e.g. Ramirez et al., 2001; Francou et al., 2003). Hence questions have been raised about the representativeness of the selected glacier network as portrayed in Vuille et al. (2008a) and Rabatel et al. (2013), although as stated above, the majority of glaciers in the tropical Andes fall into this low-elevation category and the two longest existing mass balance time series are actually from large glaciers, Antizana and Zongo.

To better assess the representativeness of the monitored glaciers, regional studies need to be promoted, where mass balance changes at the decadal scale are computed for entire mountain ranges. This can be achieved by deriving digital elevation models (DEM) from satellite data such as SRTM, ASTER or SPOT (e.g. Gardelle et al., 2013; Berthier et al., 2016), or aerial photographs. Recent sub-metric resolution satellite images (e.g., Pléiades) are also very promising (Cusicanqui et al., 2015), although their acquisition cost remains an obstacle to regional studies. Combining the geodetic method with snowline measurements derived from satellite images during the dry season would allow quantifying annual mass balance data for tens or hundreds of glaciers. However, algorithms still need to be improved to automatize the processing of satellite images (Rabatel et al., 2016).

\subsection{Glacier thickness estimates}

One bottleneck for a better quantification of glacier changes and their contribution to hydrological functioning of high-altitude watersheds is the difficulty in quantifying glacier volume and thickness distribution. As discussed in Sections 3.2 and 3.3, the only future glacier change projections including ice dynamics performed in the tropical Andes were done on the highly monitored Zongo glacier, Bolivia (Réveillet et al., 2015; Frans et al., 2015) where ice thickness was measured in-situ. However, even though more in-situ measurements on individual glaciers are needed, it is impossible to directly measure ice thickness on all the individual glaciers, given the cost, logistics, accessibility, etc. Therefore, modeling of glacier thickness is indispensable. Several modeling approaches are currently being tested 
within the Ice Thickness Models Intercomparison eXperiment (ITMIX, http://cryosphericsciences.org/wg_glacierIceThickEst.html). The efficiency of the models largely depends on the required input data (surface DEM, glacier outline, surface mass balance, surface flow velocities). Preliminary results from this intercomparison initiative (Farinotti et al., 2017) show that the availability of accurate DEMs, surface velocity fields and mass balance data allows improving the ice thickness distribution estimates. In this context, the new generation of sub-metric resolution satellite images (e.g. Pléiades, WorldView) or satellites with high temporal acquisition frequency (e.g., Sentinel-2 with a 5-day revisiting period) open new avenues for obtaining useful input data to accurately estimate glacier thickness.

\subsection{Role of clouds and regional circulation changes}

On low-latitude glaciers, the main seasonal changes in mass and energy balance are driven by humidity-related variables, and ablation and accumulation processes are closely linked. Seasonal and interannual variations in the mass balance therefore depend on cloud and precipitation properties, with net radiation being the main driver of the glacier surface energy balance (Sicart et al., 2005). Shortwave incoming radiation is particularly important during the transition from dry to wet season (October-November in the central-southern tropical Andes), when cloud cover is still low, yet the long dry season has accumulated significant amounts of dust and aerosols at the surface, which together with snow metamorphism and ice exposed due to the increasing snow line results in very low albedo values (and hence high rates of absorption of solar radiation (e.g. Wagnon et al., 2001; Gurgiser et al., 2013). Once the wet season has started and glaciers are blanketed with fresh snow and clouds reduce incoming solar radiation, this effect subsides, and melt rates are somewhat reduced. Still, significant melt rates tend to persist for most of the wet season, driven mainly by high longwave radiation emitted by convective clouds (Sicart et al., 2010, 2011). Hence snowfall (albedo effects) and clouds (radiative properties) are key drivers of the surface energy balance of tropical glaciers as their characteristics (convective vs. stratiform; low vs. high clouds, etc.) change with seasonal changes in atmospheric circulation (Sicart et al., 2016). Changing cloud properties modulate longwave radiation, but also lead to seasonal changes in the amount of incoming shortwave radiation. How cloud radiative forcing in the tropical Andes might change under future climate change scenarios is highly uncertain, yet of - paramount importance to understand future changes in tropical glaciers' energy balance. A first step in addressing this lack of understanding was taken by Sicart et al. (2016), who were able to link cloud properties and their impact on the incoming surface energy flux over tropical glaciers to changes in the atmospheric circulation on seasonal timescales. Given that climate models are better suited to simulate changes in the large-scale circulation, this might open new avenues to statistically infer related changes in cloud properties over the Andes, without having to directly rely on error-prone cloud data from the models themselves.

\subsection{Role of aerosols (black carbon) and albedo feedback}

Given the importance of albedo changes for surface energy balance during the transition from dry to wet season, when cloud cover is still low, yet solar radiation is high, deposition of solid particles such as dust, black carbon and other aerosols from air pollution, including biomass burning and fossil fuel combustion, on glaciers is of high relevance. Black carbon in particular is a major concern, given that its efficacy to contribute to snow and ice melt once deposited on a glacier is significantly higher than its radiative forcing would imply (Flanner et al., 2007). Yet this topic has received surprisingly little attention in the Andean region (e.g. Sicart and Arnaud, 2007; Schmitt et al., 2015), unlike for example the Himalaya, where a significant amount of literature on this topic exists (e.g. Ramanathan and Carmichael, 2008; Xu et al., 2009; Menon et al., 2010; Kaspari et al., 2011; Qiu, 2013; Ginot et al., 2014). Biomass burning in the Amazon basin, upwind of the tropical Andes, is likely a major source of black carbon deposition in the Andes (Pereira et al., 2011), but emission statistics and inventories over the region, as well as adequate emission, transport and deposition models are largely lacking (Molina et al., 2015). Developing such models is particularly challenging in this region, given the paucity of observational data and the complex topography leading to highly uncertain transport and mixing processes (Molina et al., 2015). Initial results obtained in the Cordillera Blanca by Schmitt et al. (2015) seem to suggest that deposition levels of black carbon are higher on glaciers that are located closer to population centers, when compared to glaciers that are in more remote locations, indicating that local sources of pollutants may outweigh long-distance transport. This result however, has yet to be confirmed at other sites in the Andes. Such local sources for black carbon can include diesel-powered vehicles, residential use of wood, waste, etc. for heating and cooking, as well as local grassland fires, both anthropogenic or natural (Roman-Cuesta et al., 2014). Deposition of ash from volcanic eruptions is also locally important (Schotterer et al., 2003), even though it is not a result of climate change and the forcing is time-limited, as the volcanic aerosol concentration drops rather quickly once the eruptions ends. Some studies have also used ice cores to analyze historical air pollution levels dating back to pre-Incan times (e.g. Eichler et al., 2015; Uglietti et al., 2015), but they focused mostly on trace elements such as $\mathrm{Pb}$, that are emitted from metallurgic activities. Given the paucity of data on this topic, its relevance for glacier energy balance in the Andes is somewhat uncertain. Yet the lessons learned from similar studies in the Himalaya indicate that further research to obtain better data on this topic is warranted. For example only one high-elevation Global Atmospheric Watch (GAW) site measuring atmospheric air pollution exists in all of the tropical Andes, located at the Chacaltaya Observatory in the Cordillera Real, Bolivia (Molina et al., 2015). This network should be extended to include a similar station in the northern humid tropical Andes. This is all the more important as several mid- to large-sized cities exist in the tropical Andes (La Paz, Cuzco, Quito, Bogota), all emitting significant quantities of air pollutants, including black carbon, that could reach nearby glacierized mountain ranges.

\subsection{Role of groundwater}

One of the major uncertainties related to water storage terms in the tropical Andes relates to groundwater. Very little is still known about how aquifers in the region are recharged and to what extent they could contribute to maintaining a crucial base flow in rivers during the dry season. Baraer et al. (2015) and Gordon et al. (2015) analyzed the contribution of groundwater to river discharge in several glacierized catchments of the Cordillera Blanca, Peru. Baraer et al. (2015) applied a hydrochemical mixing model, including major ions and stable isotopes to determine the extent to which glacier runoff during the dry season may be complemented by a contribution from the underlying aquifer. In all four valleys they surveyed, the groundwater contribution to runoff was above $24 \%$ during the dry season, suggesting that groundwater provides a substantial contribution to river discharge from these glacierized catchments. Another study in a proglacial catchment of the Cordillera Blanca by Somers et al. (2016) confirms these results. Their study indicates that river discharge during the dry season experiences a net gain of almost $30 \%$ from the underlying aquifer. Both Gordon et al. (2015) and Somers et al. (2016) stress, however, that groundwater itself is at least partially recharged through glacier meltwater. Hence it remains an unresolved question to what extent the hydrology of the underlying aquifer itself will be affected by continued glacier retreat and eventual complete disappearance. An additional challenge stems from the difficulty in correctly describing the regional extent of the different aquifers, given the heterogeneous lithology and complex geology characterizing the upper reaches in many of the glacierized catchments. 


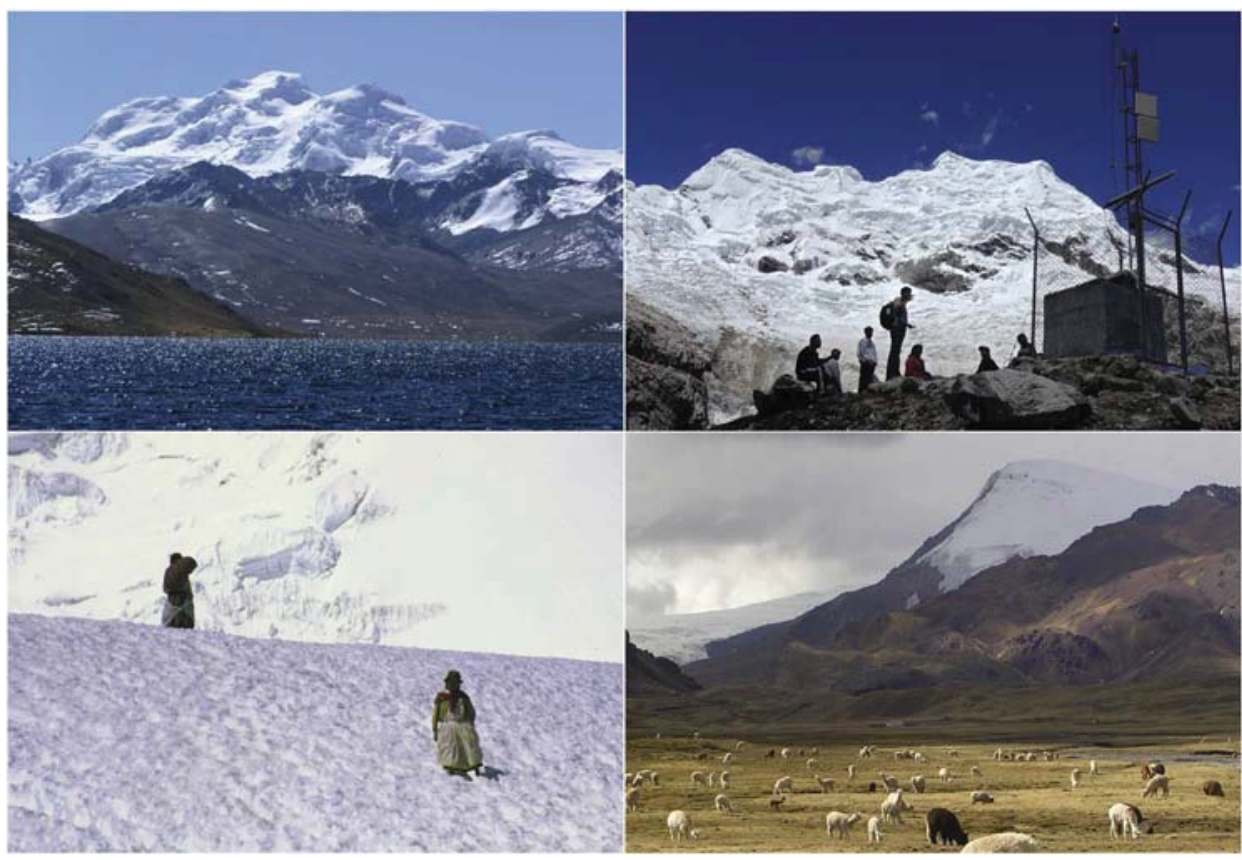

Fig. 5. Examples of human activities and environmental services that may be affected by glacier retreat. Top left: Hydropower production - Laguna Sibinacocha in the Cordillera Vilcanota, Peru. The dammed lake reservoir is fed by glacial meltwater and serves electricity production (photo: C. Huggel). Top right: Glacial hazards - An early warning system on Laguna 513, Cordillera Blanca, Peru, a glacier lake that formed as glaciers receded during the past decades. The warning system includes geophones and cameras transmitting pictures of dam and mountainside in real time (photo: C. González). Bottom left: Alpine tourism - Women on Mt. Illimani, Cordillera Real, Bolivia, serving as porters for alpine climbing expedition (photo M. Vuille). Bottom right: Andean wetlands - Lamas and Alpacas grazing in wetland maintained by glacier meltwater downstream of Quelccaya ice cap, Cordillera Vilcanota, Peru (photo M. Vuille).

Some aquifers may be fractured, as is the case for example in the Antizana catchment in Ecuador (Favier et al., 2008) or consist of porous media, as is the case in the Quilcayunca catchment in Peru (Baraer et al., 2015).

\section{Impacts on socio-economic, environmental and cultural systems}

\subsection{Water use}

Water is used for a variety of industrial purposes in the tropical Andes, but the two main industrial sectors that rely on a steady supply of water are hydropower production (see illustrative example in Fig. 5) and mining. Hydropower constitutes a major component of the power mix in many Andean countries (Vergara et al., 2007). In Peru, for example, it accounts for $54 \%$ of the energy production (Drenkhan et al., 2015). With the energy demand in Peru currently increasing at a rate of 5.4\% per year (Drenkhan et al., 2015), this capacity is projected to grow rapidly (Finer and Jenkins, 2012). Yet glacier retreat might at least in some regions, such as the Cordillera Blanca, Peru, have a negative impact on hydropower production, because of the likely decrease in river discharge during the dry season (Mark et al., 2010; Chevallier et al., 2011; Baraer et al., 2012; Condom et al., 2012;). Because glacier runoff variability varies across each basin, and because glacier shrinkage for larger glaciers will generate increased runoff rather than an immediate reduction in discharge, which may be the case for smaller glaciers or particular basins, it is difficult to draw decisive conclusions about how, when, and where glacier retreat will affect hydropower generation (Carey et al., 2017). In some cases, glacier shrinkage will increase runoff for decades into the future, while in other locations discharge reduction may already be underway, thereby having negative water use impacts. When glacier runoff declines, it will often be necessary to construct additional storage to maintain the same level of power production. In the past, reservoir building has led to opposition and resistance from local residents (e.g. Carey et al., 2012a; Rasmussen, 2016). While water use for hydropower production is not in itself a consumptive use in the sense that it would lower the overall availability of water (except for some evaporative loss in reservoirs), it requires strong flow regulation. This may either be beneficial or detrimental to other water uses, depending on the scope for multi-objective optimization of reservoir operations. Yet, many existing reservoirs in the tropical Andes, including the Cañon del Pato hydropower dam on the Santa River, are already operated as multi-purpose reservoirs. Furthermore, hydropower installations may be faced with increased sediment influx as glacier retreat will increasingly expose bare slopes and lead to increased erosion and discharge of suspended sediments (Finer and Jenkins, 2012; Godon et al., 2013). They also threaten ecological connectivity between high and lowland river species along river systems and pose barriers for migrating species, in particular on the eastern slopes of the Andes, where over 150 new dams were in a planning phase in different Andean countries in 2011 (Finer and Jenkins, 2012).

Mining is a major economic sector in many Andean nations and also has a very large water footprint as water is used for leaching, flotation and concentration processes of ore. According to Carey et al. (2014), producing one ounce of gold in the Rio Santa valley, Peru, in 2008 required approximately $25 \mathrm{~m}^{3}$ of water. Bebbington and Bury (2009) report that mining claims in Peru have increased exponentially, with mining concessions in 2008 covering $11 \%$ of the entire surface area of the country. Many of them are located in watersheds that are already under significant water pressure, supplying drinking water to large coastal cities, such as Lima. However, most water use in mining is nonconsumptive and therefore returned to the river. As a result, mining impacts on downstream water availability tends to be limited, but it may exacerbate local water stress or reinforce the impact of glacier melt. Additionally, the potential impact on contaminants and sediment load can be significant, with glacier loss opening up new high-elevation and fragile lands to mining that release cyanide and other contaminants into downstream water supplies (Buytaert and Breuer, 2013; Bury, 2015). Quantitative analysis of daily rainfall and discharge variability in the Tablachaca River $\left(3132 \mathrm{~km}^{2}\right)$ and the Santa River $\left(6815 \mathrm{~km}^{2}\right)$ watersheds by Morera et al. (2013) for example, shows that mining activity leads to much higher specific suspended-sediment yield (2204t $\mathrm{km}^{-2} \mathrm{yr}^{-1}$ ) in the Tablachaca River, despite a very similar hydroclimatic setting. Maybe most important, however, is the impact on water quality as ore mining often leads to acid mine drainage leaching heavy metals and other pollutants into nearby rivers. Historically pollution from mining has been a major problem for water quality, as acid mine drainage from mine wastewater, including contaminants such as $\mathrm{As}, \mathrm{Pb}$ and $\mathrm{Cd}$ has repeatedly leaked into streams and rivers (Bebbington and 
Williams, 2008; Rodbell et al., 2014). Since mining operations generally occur at high elevations in the headwaters of rivers (Bebbington and Bury, 2009), these pollutants have the potential to affect large portions of rivers downstream. Water quality can also drastically decline due to glacier retreat as sulfide-rich formations may become exposed and start to leach into glacial streams (Fortner et al., 2011). In the Peruvian Cordillera Blanca, for example, some of the streams sampled by Fortner et al. (2011) have Pb and Ni concentrations that significantly exceed Peruvian drinking water standards or the water quality standards set by the World Health Organization (WHO). Similarly other ions such as $\mathrm{Al}$, Fe or the water $\mathrm{pH}$ exceed standards suggested for human consumption (Fortner et al., 2011). The fact that glacier retreat will lead to a reduction in dry season streamflow, further exacerbates the problem, as pollutants will become more concentrated during this season (Fortner et al., 2011).

Glacier retreat also affects water use in large-scale export-oriented agriculture and subsistence farming and pastoralism (López-i-Gelats et al., 2015; Postigo et al., 2008; Young, 2008). Below Peru's Cordillera Blanca, glacier runoff plays an important role in irrigation, including for the Chinecas and Chavimochic projects that divert Santa River water into several neighboring watersheds to nourish agricultural production (Bury et al., 2013; Carey et al., 2014). While other factors including Peru's water distribution policies, competing interests for Santa River water, international demand for crops such as asparagus, and infrastructure construction such as dams, influence Chavimochic and Chinecas, glacier runoff rates have the potential to influence agricultural production, as well as livelihoods, potable water, and national gross domestic product (GDP).

\subsection{Glacier hazards}

The tropical Andes have been the site of repeated large glacier-related disasters throughout modern history. Among the most devastating disasters were glacier lake outburst floods (GLOFs), ice and rock avalanches and lahars from ice-capped volcanoes, especially in Colombia and Peru (Pierson et al., 1990; Evans et al., 2009; Carey, 2010).

Glaciers have retreated throughout most of the 20th century and lakes often formed in the foreland, dammed by bedrock or moraines that were deposited during the Little Ice Age or other periods of glacier advance. Several studies have documented the increase in number and size of the lakes in the tropical Andes over recent decades (e.g. LopezMoreno et al., 2014; Hanshaw and Bookhagen, 2014). The Cordillera Blanca in Peru has seen multiple disasters with outburst floods affecting downstream communities in the past (Carey, 2010; Carey et al., 2012a; Schneider et al., 2014). In 1941 a third of the city of Huaraz was destroyed by a GLOF, causing approximately 1800 fatalities (Carey, 2010). Lake Palcacocha, which caused this 1941 GLOF, is now once again estimated to pose significant risks to downstream communities, especially Huaraz, as the lake contains approximately 17 million $\mathrm{m}^{3}$ of water, compared to an estimated 10-12 million $\mathrm{m}^{3}$ when the GLOF occurred in 1941 (Vilímek et al., 2005; Emmer et al., 2014; SomosValenzuela et al., 2016). GLOF risks exist throughout the tropical Andean region even though they have been most destructive in the Cordillera Blanca (e.g. Hoffmann, 2012; Cook et al., 2016).

Landslides, ice or rock avalanches, triggered by processes such as earthquakes, heavy rainfall, gradual destabilization of slopes or a combination thereof, have repeatedly led to cascading processes by impacting glacier lakes and causing outburst floods. However, large mass movements can also represent a major hazard on their own. The most prominent and disastrous events in the tropical Andes are the 1962 and 1970 Huascarán rock-ice avalanches, destroying the towns of Ranrahirca and Yungay with 650 and 6000 fatalities, respectively (Evans et al., 2009). Flow transformations from avalanches to highly mobile debris flows due to thermal energy production and melting of snow and ice, such as at the Huascarán events, make these processes a far-reaching hazard for downslope areas. Similar large and destructive mass flows (termed lahars) with reaches of up to $100 \mathrm{~km}$ and beyond have also been observed on ice-capped volcanoes across the tropical Andes. Medium-size volcanic eruptions may be sufficient to melt snow and ice and cause massive lahars such as on Nevado del Ruiz, Colombia, where 23,000 people were killed in 1985 (Barberi et al., 1990; Pierson et al., 1990). Most ice-capped volcanoes in the tropical Andes are being monitored now and some have early warning systems in place but major concerns persist for high risk areas such as Cotopaxi volcano, Ecuador, where at least 100.000 people reside in the path of the lahar that occurred in 1877 (Pistolesi et al., 2013).

Physical process understanding and modeling, and field evidence from the past and present suggest that periods of warming and associated glacier shrinkage and permafrost degradation result in decreasing slope stability (Gruber and Haeberli, 2007; Huggel et al., 2012; McColl and Davies, 2013). In the tropical Andes no systematic analysis concerning observed or projected slope stability exists and little is known on the related impacts of climate change on populations and infrastructure in the region. Efforts are underway to assess location and dimension of new lakes as a result of ongoing and future glacier retreat, allowing an estimate of the impacts of potential lake outburst flows (Colonia et al., 2017). Research should focus on a comprehensive analysis of geophysical (earthquakes, volcanic activities) and climatic (warming, extreme events) triggers of mass movements and flows, and cascading effects on lakes and downstream areas and communities to inform disaster risk reduction and adaptation strategies.

Glacier-related risks of course exist not only because of geophysical dynamics but also because of exposed and vulnerable human populations, a topic lacking sufficient research for the tropical Andean region. Studies demonstrate the need for comprehensive and holistic approaches to risk reduction (Oliver-Smith and Hoffman, 1999; Hegglin and Huggel, 2008; Carey et al., 2012a). These involve not only early warning systems and educational and awareness programs, but also more comprehensive approaches that analyze class standing and socioeconomic disparities, building codes, land use planning, urban development, cultural values, risk perceptions, spiritual understandings of extreme events, government policies, and infrastructure placement and construction, among many other factors. Moreover, research has pointed to the underlying historical processes by which certain segments of the population become more vulnerable to hazards over time, whether the more marginalized Quechua-speaking subsistence farmers living in rural areas, poorer communities living in new settlements along the margins of rivers where GLOFs can pass, or Spanish-founded towns and cities built on alluvial fans where GLOFs and rock and ice slides funnel into during disaster events (Oliver-Smith, 1999; Carey, 2010).

\subsection{Downstream ecological impacts}

While projected future changes in Andean biomes due to climate change remain somewhat uncertain (Tovar et al., 2013), there are many impacts of climate change on Andean ecosystems that are already being felt, such as the upslope migration of the Andean timberline, ecotones and vegetation zones and increasing continental insularity (Feeley and Silman, 2010; Feeley et al., 2011; Anderson et al., 2011; Lutz et al., 2013; Anthelme et al., 2014; Morueta-Holme et al., 2015; Zimmer et al., 2017), changes in species composition of lake ecosystems (Michelutti et al., 2015) or emergence of new invasive species, pests and vectorborne disease (e.g. Seimon et al., 2007; Dangles et al., 2008; Siraj et al., 2014).

Accelerated glacier melt can have both direct and indirect impacts on high Andean aquatic ecosystems fed by meltwater, such as streams, lakes and wetlands. Direct impacts of glacier melt are related to changes in streamflow, hydrological variability, water temperature, turbidity and chemistry of glacier-fed rivers. Glacial meltwater contribution to these systems is a main driver of spatio-temporal biodiversity patterns, species composition of natural plant and animal communities, as well as 
key ecosystem processes such as primary production. For instance, glacier-fed streams contribute to environmental heterogeneity in river networks at the catchment level, promoting regional biodiversity (Jacobsen et al., 2012; Cauvy-Fraunié et al., 2015; Quenta et al., 2016). Jacobsen et al. (2012) first pointed out that highly specialized communities exist in Andean glacier-fed rivers. Based on studies in rivers that are supplied by glacial meltwater from glaciers on Mt. Antizana in the Andes of Ecuador, they were able to predict that $11 \%$ of invertebrate species, including several endemic species, may become permanently extinct if glaciers completely disappeared from the region. A similar result has been demonstrated for bofedales, high Andean wetland complexes, in Bolivia (Quenta et al., 2016).

The exact ecological functioning of these invertebrate species and their role played in the food chain is poorly known. The effect of changes in species composition are therefore difficult to predict, as are potential altitudinal range shifts in response to changes in in-stream environmental conditions due to reduction in glacial cover in the catchment (Jacobsen et al., 2014). As demonstrated by Cauvy-Fraunié et al. (2015), the glacial meltwater provides for a spatial filter, essentially insulating the highly adapted species from competition from other more common generalist species unable to cope with the harsh environmental conditions in glacier-fed rivers, and thus excluded from dispersing upstream. With a reduction in glacial meltwater this environmental filter will weaken or eventually completely disappear, allowing colonization through more competitive species from further downstream leading to the possible extinction of these highly adapted endemic 'glacial' species. These results were confirmed more recently in a flow manipulation study, where the glacial meltwater contribution was artificially manipulated (diverted and after a period of time reintegrated) and the resulting changes in algae and macro-invertebrate composition monitored over a period of several years (Cauvy-Fraunié et al., 2016). Their results highlight that following a reduction in glacial meltwater, benthic algal and macroinvertebrate herbivore biomass increased and macroinvertebrate community composition changed within a matter of days to a few weeks, while recolonization by the original species after restoring the previous flow regime takes approximately 30 times longer.

With increased runoff from glacial recession, turbidity (from suspended glacial flour) will also increase in lakes downstream, thereby decreasing water transparency (Hylander et al., 2011). Input of glacial flour creates horizontal gradients in attenuation of light and ultraviolet radiation (UVR), which strongly affect both distribution and behavior of phyto- and zooplankton. The input of glacial flour thus creates a refuge for species that are sensitive to high UVR exposure. When the glacier has vanished, this habitat may disappear, nutrient levels will shift and food resources increase. Hence, glacier melting will probably have profound effects on both species composition and behavior of several planktonic taxa with potential effects on the food web (Hylander et al., 2011; Laspoumaderes et al., 2013).

Glacier melt may also have less direct impacts through alteration of the water balance of downstream ecosystems. For instance, infiltrating glacier meltwater may influence groundwater flows and soil water content, in particular in regions with groundwater exfiltration or shallow groundwater levels. Additionally, changes in streamflow magnitude may affect water inflow, wetness, and the hydrological regime of downstream wetlands (see illustrative example in Fig. 5). Indeed a recent study in the páramo environment of the Colombian Andes suggests that glacier retreat and the excess meltwater, in combination with increased temperature may have led to higher rates of peat accretion in tropical wetlands (Benavides et al., 2013). The enhanced accumulation of organic biomass may, however, only be temporary, if glacier meltwater indeed spurred this enhanced carbon uptake.

Bofedales, wetlands in the dry Puna of the southern tropical Andes (Fig. 5, see also Squeo et al., 2006), are among the most sensitive ecosystems and strongly affected by changes in meltwater discharge from glaciers upstream (Loza Herrera et al., 2015; Dangles et al., 2017).
For example Polk et al. (2017) recently suggested that the spatial extent of these wetlands in the Cordillera Blanca may follow the same 'peak water' concept as applied to river discharge, with a temporary expansion as more meltwater leads to increased river runoff. In the long-term, however, these bofedales will likely shrink in size due to the lack of sustained meltwater inflow, which may lead to soil desiccation and wetland degradation, negatively affecting species richness and the ecosystems' ability to provide environmental services such as carbon and water storage (Polk et al., 2017).

\subsection{Social impacts and socio-political conflicts}

Growing concerns surrounding water allocation have led to an increasing number of conflicts between industrial and local demands that have different priorities regarding control, regulation and access to water. Studies suggest that the root problem of these conflicts tends to lie in rising water demand, often exacerbated by inequitable water allocation and lack of adequate water governance, that could provide for a legal framework how water regulations are made and implemented (Vuille, 2013; Carey et al., 2014; Carey et al., 2017). In Cotacachi, Ecuador, researchers note increased water competition for irrigation and agriculture in recent years but link the conflicts not only to reduced glacier runoff but also to precipitation decline, government policies, water management strategies, and other human variables influencing water distribution (Rhoades et al., 2008; Skarbø and VanderMolen, 2014). In Bolivia, McDowell and Hess (2012) also point to interconnected drivers of water shortages, including glacier runoff reduction, farmers' crop choices (with different crops requiring different quantities of irrigation water), and the difficulty of differentiating between precipitation-fed irrigation and the use of glacier runoff.

Drenkhan et al. (2015) give examples of several incidents in the Andes of Peru, where local residents successfully protested against the construction of dams and reservoirs for energy production, either because of traditional beliefs that lakes were sacred, fear over future livelihoods, deep mistrust of regional authorities and institutions or inability to come to an agreement with hydropower companies on how to regulate and allocate water from lakes to the different users. One case involves Lake Parón in the Cordillera Blanca, Peru, where local residents, seized control of the reservoir from a hydroelectric company in 2008. This reservoir had been built as an adaptation measure, to allow lowering and regulating the lake level to prevent dangerous GLOFs (Carey et al., 2012b; Lynch, 2012). However, installing regulating capabilities at the reservoir led to very different views between local residents and the hydropower company operating the dam, on how the water release should be managed. Locals sought to change the timing and rate of water release from the reservoir because they saw hydropower management (releasing high quantities of water for peak hydroelectricity generation) as detrimental to small-scale irrigation infrastructure, tourism development, and local water needs for farming and human consumption (Carey et al., 2014).

An additional problem facing many Andean nations is that their institutions and authorities in charge of water regulations have often undergone frequent changes in personnel and institutional hierarchy and standing, affecting their ability to make and implement decisions. This lack of continuity has hampered their ability to sustain a long-term perspective on water legislation and implementation (Lynch, 2012) or build trust and lasting channels of communication with local communities. The multitude of institutions and offices involved in glacier monitoring, water resources management and risk assessment, further complicate the situation. As a result many of these water conflicts remain unresolved and the struggle over control and access to water continues.

\subsection{Tourism}

Tourism plays a significant role in regions where cultural tourism 
(e.g. Inca trail, Macchu Picchu) or mountaineering and alpine recreation such as trekking and sightseeing attract a significant number of foreign or non-local visitors. This mountain tourism can be intrinsically tied to climate change as glaciers add to the attraction for many alpinists who wish to scale the highest peaks of the tropical Andes (see illustrative example in Fig. 5). Glaciers and glacial lakes in Peru's Cordillera Huayhuash, for example, are important features attracting trekkers and mountaineers, and glacier shrinkage that opens passes and routes is drawing an increasing number of tourists into the region as mountain access becomes easier and quicker in these newly ice-free areas (Bury, 2008). In several other places, mountain guides had to change their routes to the summits as continued glacier retreat has rendered some of the traditional routes too dangerous. At Peru's Pastoruri Glacier in Huascarán National Park, the regional government has shifted tourism from a previous emphasis on visiting the glacier for hiking, skiing, and sightseeing to highlighting the shrinking glacier as part of a Route of Climate Change, to illustrate the negative effects of climate change on glaciers. Further, tourists to the Pastoruri area now visit geophysical and archaeological resources, including cave paintings and dinosaur footprints, rather than the diminishing glacier (Gagné et al., 2014).

Chacaltaya glacier in the Andes of Bolivia (Ramirez et al., 2001; Francou et al., 2003) is a particularly interesting example as it was advertised as the world's highest ski resort, with a peak elevation of $5400 \mathrm{~m}$ a.s.l. A ski lift was installed on the slopes in the late 1930s and regular skiing competitions were held on the mountain, with tour operators offering day-trips to the mountain to ski on the world's highest ski slopes (Kaenzig et al., 2016). With the complete disappearance of the glacier in 2009 , the situation changed, as skiing is no longer possible. The easy access from La Paz, its $360^{\circ}$ panorama and its ideal elevation to acclimate for high altitude climbing, however, have maintained the attractiveness for tourists despite the disappearance of the glacier. Some have even suggested creating a climate change museum at the summit and using the disappearance of the glacier as an attraction to draw tourists to the site, allowing them to witness the rapid changes that are occurring (Kaenzig et al., 2016). While clearly not applicable directly to all other sites, the cases of Chacaltaya and Pastoruri offer a glimpse of possible ways for the tourism industry to adapt and potentially diversify its portfolio toward additional activities besides skiing or mountaineering.

\subsection{Cultural beliefs}

Several studies have pointed out that cultural belief systems, spiritual values and perceptions form an integral part of water management practices in the tropical Andes (e.g. Bury et al., 2011; Carey et al., 2012b; Drenkhan et al., 2015). These aspects shape how local residents view and respond to the apparent changes in their environment, including changing climatic conditions or glacier retreat (Young and Lipton, 2006; Carey et al., 2014). Jurt et al. (2015) for example, based on interviews conducted in a village at the base of the Cordillera Blanca, report how local inhabitants perceive the retreating glaciers as a threat to their livelihoods and how it further exacerbates their concern regarding water scarcity and unjust water allocation. Brugger et al. (2013) also reveal the deep emotional attachments that people in Peru (and elsewhere) have to glaciers and glacier loss, a feeling that Rhoades et al. (2008) also documented around Cotacachi in Ecuador, where there has been significant emotional impacts of the changing landscape amidst glacier loss. Young and Lipton (2006) report that local residents around the Cordillera Blanca have changed place-names because of glacial retreat.

Glacier retreat, however, is not always seen only as a consequence of a changing climate, but is often also blamed on local activities such as extracting ice blocks from the glacier for sale, or on tourists and scientists, who walk and climb on glaciers, make measurements on them and pollute and shatter the ice (Jurt et al., 2015). On Mt.
Ausangate in Peru, for example, a catholic pilgrimage would end with local residents cutting blocks of ice from the glacier and bringing them back to their families as they were considered to have strong healing power. With the rapid retreat of the glacier, this custom has been stopped and guards now make sure that no ice is removed (Allison, 2015). Similarly candles that are lit around the glacier during this procession have been reduced in size to limit their impact on glacier melt. In this framework, glacier retreat is seen more as a response to local actions by locals or foreigners, rather than as a consequence of global change. The response to these changes can vary, depending on perceptions of the actors involved. Postigo (2014) documented how rural populations in the Andes have responded to perceived changes in climate extremes and glacier retreat by creating wetlands, modifying their agricultural calendar and the way fields are being irrigated. Hence environmental aspects of water demand, use and allocation are clearly intertwined with social and cultural aspects that are often equally important for understanding the impacts on local society and its response to these external forces. Allison (2015) for example documents how glacier retreat is not simply seen as just a material loss, but has implications for the local identity of rural communities and the way they see themselves and their surroundings. After all, in many places mountain glaciers are viewed not just as sources of freshwater but are sacred places, home of gods or even living beings.

\section{Challenges and opportunities for adaptation}

\subsection{The need for adaptation}

Climate and socio-environmental changes pose major challenges to the tropical Andes, in particular with respect to the sustainable supply and use of freshwater and glacier and high-mountain hazards as seen in the previous sections. The adaptation challenge needs to be addressed by comprehensive and integrative strategies that consider science, culture, policy and practice, and involve local populations; thus being of fundamental transdisciplinary nature (Payne and Shepardon, 2015). Risks from natural hazards such as glacier lake outburst floods, for example, should be evaluated through integrated hazard and risk analysis including accurate simulations of the impacts, using physicallybased numerical models, but also analysis of societal needs, economic agendas, political conflicts, socioeconomic inequality and cultural values that all influence vulnerability and risk perceptions. Effective adaptation to glacier-related hazards should thus involve detailed planning and implementation of preventive measures, such as identification and prioritization of hazards (hazard maps), building codes, zoning regulations and land use planning, definition of evacuation routes, early warning and alarm systems, emergency protocols, education and outreach programs, to a name a few pertinent measures (e.g. Huggel et al., 2012; Schneider et al., 2014; Muñoz et al., 2016).

In many Andean watersheds, local inhabitants are acutely aware of their rapidly changing environment and the retreat of glaciers (Young and Lipton, 2006; Bury et al., 2011; Jurt et al., 2015). Although their response and coping strategies vary widely, local populations have often developed their own environmental knowledge and sense of adaptation or coping strategies with these types of hazards over time. For instance, in the Cordillera Blanca some lakes were artificially drained or they had their level lowered proactively, e.g., through construction of siphons to reduce the threat level. Residents often evaluate such risks differently from engineers, scientists, policymakers, and non-governmental organizations, thus making it critical to understand not only the biophysical changes in Andean regions but also the societal drivers of vulnerability and risk perceptions (Oliver-Smith, 1999; Carey, 2010; Boelens, 2014). Not all forms of adaptation to natural hazards may be equally favored by local residents, as their acceptance may depend on perceived risk, cost of implementation, loss of autonomy, level of distrust toward authorities and lack of confidence in public institutions (Carey et al., 2012a). Additionally, in many places 
the changes currently under way are evolving so rapidly that they have moved beyond the local historical framework. Moreover, the use of scientific information in adaptation projects and measures in the Andes is quite diverse, yet it is common that the actual measures are disconnected from scientific results and recommendations (Huggel et al., 2015). These issues highlight the need for comprehensive adaptation approaches and indicate the associated multiple challenges.

\subsection{Adaptation challenges and constraints}

Research on the affected natural and human systems of the tropical Andes is often incomplete, which makes the design and implementation of effective adaptation measures difficult. The spatio-temporal availability and quality of environmental and socio-economic data is limited over much of the tropical Andes, thus increasing the uncertainty inherent to scientific assessments (Vuille, 2013; Salzmann et al., 2014). How socio-economic, political, and biophysical forces intersect during complex processes of global change - and which factors are most important to address, and for which populations - therefore make adaptation efforts extremely challenging.

Some uncertainty in what entails effective adaptation stems from the lack of an adequate database (Salzmann et al., 2014) and insufficient exchange of information between the different institutions, whether public or private. Adaptation measures should ideally be based on an assessment of both climate change-related impacts and societal dynamics, which require data that are applicable at local to regional scales (Viviroli et al., 2011; Huss et al., 2017). Yet in the tropical Andes such a database is often missing, be it for climatic, glaciologic, hydrologic, or other environmental or socio-economic aspects. Indeed the paucity of data and its often low quality provide a major obstacle for developing and implementing adequate adaption measures that guarantee a sustainable integrated water management system (Salzmann et al., 2009; Vuille, 2013; Huggel et al., 2015). Therefore monitoring networks should be strengthened and standardized, while securing long-term funding to maintain these networks should be a priority. Establishing data sharing platforms, which enable access to the data for all users would enhance research and improve quality and consistency across studies and regions (Salzmann et al., 2014). This applies not only for climatic, glaciological or hydrological monitoring but also for the analysis of societal conditions such as risk perceptions and vulnerability.

Poor availability and quality of data affect the development of future scenarios, and there is in fact a paucity of scenarios available for the tropical Andes, in particular with regards to socio-economic development such as expressed in water demand. For instance, modeling and analysis of future water scarcity in Andean regions affected by shrinking glaciers need to consider human variables to realistically simulate future paths of key drivers and relevant factors that determine water use, allocation and regulations (e.g. Caballero et al., 2004; Escurra et al., 2014; Nazemi and Wheater, 2015). In the framework of efforts by the IPCC, researchers in recent years have begun to develop a new scenario framework with a more comprehensive set of global and regional scenarios (Moss et al., 2010; Nakicenovic et al., 2014). The RCP's defining the radiative forcing by 2100 are complemented by the Shared Socio-Economic Pathways (SSP) which describe plausible alternative trends in the evolution of social and natural systems over the 21 st century, with narrative storylines and quantified measures of development (O'Neill et al., 2014). These types of quantitative future scenarios have rarely been developed for regions in the tropical Andes and even less considered for supporting and informing adaptation strategies. Nevertheless, some recent studies have taken first steps in the direction of current and future scenarios of water allocation simulated in a hydrological model (Condom et al., 2012). Additional types of models, which argue for the integration of social sciences into hydrologic modeling, exist. Such models, which include hydrologic network management simulations or interactive human-hydrologic modeling, could serve as a starting point for modeling approaches in the Andes (Blair and Buytaert, 2016; Carey et al., 2014).

\subsection{Opportunities and future directions}

Incomplete and missing data and information on socio-environmental conditions should not paralyze the development and implementation of adaptation plans. A common approach taken in the face of multiple uncertainties are robust, low-regret adaptation strategies (Hallegatte, 2009; Wilby and Dessai, 2010). In the sense of such robust adaptation we consider the following components particularly relevant in the Andes context: (i) reducing multiple stressors and increasing efficiency of climate sensitive processes and structures; (ii) strengthening participatory approaches and reducing social inequalities; (iii) strengthening the science-policy and institutional interfaces. In the following we discuss these three components.

Ancillary stress factors affect the adaptive capacity of the population. Local inhabitants which at the same time are confronted by multiple stressors such as poverty, land scarcity, weather extremes, or poor water quality, all requiring expenditure of financial, human or social capital, are more likely to be vulnerable to the negative impacts of climate change (Valdivia et al., 2010; Sietz et al., 2012; McDowell and Hess, 2012). This increased vulnerability is not necessarily a function of increased exposure to the negative effects of climate change and glacier retreat, but rather a reflection of the limited infrastructure and lack of access to financial and technological resources that would allow them to adapt. For instance, many local communities relying on glacier meltwater in the Andes are using inefficient or deficient water channel and irrigation structures, implying very substantial water losses. Increasing their efficiency and more generally removing ancillary stressors can provide some immediate short-term benefits, which is important from an adaptation perspective as it increases the local acceptance of the project. It can also help in quantifying the benefits of adaptation vs. non-adaptation, which is otherwise often difficult since adaptation tends to emphasize longer-term rather than short-term benefits.

Empirical research in the Andes region suggests that participatory approaches that value and incorporate perceptions of local communities are fundamentally important if adaptation is to be successful, culturally acceptable and sustainable over longer periods of time (Salzmann et al., 2009; Valdivia et al., 2010; Lasage et al., 2015). These types of approaches focusing on local vulnerability are often referred to as 'bottom-up' as opposed to scenario-driven 'top-down' approaches (Buytaert et al., 2014; Huggel et al., 2015). In this framework views shaped by the local political, social and cultural context are integrated in any adaptation measure to improve people's livelihood and increase their resilience toward climate change impacts. This approach may facilitate better acceptance of adaptation measures, as it allows incorporating and taking advantage of already existing local knowledge on climate adaptation. Nonetheless, while top-down approaches have been criticized, Huggel et al. (2015) point out that some sort of a blended approach that considers both top-down and bottom-up aspects may work best, as it allows integrating results from scientific assessments in the adaptation process.

An important direction for future work is to augment households' livelihood options so they can chose between different adaptation strategies in the face of short- and long-term glacier runoff variability and glacier hazards. For example, in places like Peru's Chavimochic project in the La Libertad coastal region, the irrigation water for a halfbillion-dollar export-agriculture industry, potable drinking water for nearly 800,000 residents of Trujillo, jobs for $>60,000$ people, and energy for some inhabitants generated by a small Chavimochic hydroelectric station all hinge on the availability of Santa River water (Bury et al., 2013; Carey et al., 2014; Drenkhan et al., 2015). This kind of single-option resource for industries, energy production, water supplies, and livelihoods must be addressed and replaced by multi-purpose 
strategies that can provide a more robust form of adaptation. In some cases, regulating glacial lakes can generate co-benefits in terms of disaster risk reduction, water resource management and energy production (Haeberli et al., 2016), but the legal, social, cultural and political constraints for implementation are considerable.

Adaptation is typically implemented across a range of institutions and actors, ranging from scientific institutions, international cooperation, non-governmental organizations, national, provincial and local governments, and local population. The convergence of these actors' needs, interests and objectives requires developing strong interfaces between science, policy and other stakeholders. This can be a significant challenge since expectations, perceptions and perspectives among these actors often vary substantially. Adaptation is an iterative process in which framing of the problem, scientific assessment of impacts, vulnerabilities, risks and ultimately definition and implementation of adaptation strategies constantly need to be reevaluated and discussed among the all stakeholders (Huggel et al., 2015). This requires functioning channels of communication and platforms of exchange among science, society, and policy to jointly evaluate progress or failure of a project and find a consensus among all actors. This is especially important in international projects, to ensure that the international cooperation is aligned with the national and regional needs and priorities (Vuille, 2013). Involving local and national institutions from the outset in planning and managing of adaptation projects represent a key element for successful adaptation and will help strengthen their institutional standing (Drenkhan et al., 2015). In the end, reducing the vulnerability and increasing the resilience toward impacts associated with climate change-induced glacier retreat requires a constant risk assessment that is informed by the natural and social sciences, but is based on a participatory approach that includes local values, traditions and perceptions.

\section{Acknowledgements}

This study was produced under the umbrella of the Andean Climate Change Interamerican Observatory Network (ACCION, grant SLMAQM-11-GR-086 to M. Vuille), funded by the Bureau of Western Hemisphere Affairs of the United States Department of State. M. Vuille also gratefully acknowledges support from the International Hydrologic program (IHP) of the United Nations Educational Scientific and Cultural Organization (UNESCO). M. Carey's work was supported in part by the US National Science Foundation under grant \#1253779. C. Huggel and N. Salzmann were supported by the Swiss Agency for Development and Cooperation through the Glaciares + project in collaboration with CARE Peru, and C. Huggel by the project AguaFuturo supported by the Swiss National Science Foundation (project no. 205121L_166272). A. Rabatel, T. Condom and J.E. Sicart acknowledge the contribution of LabEx OSUG@2020 (grant ANR-10-LABX-56), the Laboratoire Mixte International GREAT-ICE funded by the French Institut de Recherche pour le Développement (IRD) in collaboration with the Escuela Politécnica Nacional del Ecuador, Universidad Mayor de San Andrés in La Paz, and the French Service National d'Observation GLACIOCLIM. W. Buytaert acknowledges funding of the UK Natural Environment Research Council (contract NE/K010239/1). We acknowledge the World Climate Research Programme's Working Group on Coupled Modeling, which is responsible for CMIP, and we thank the climate modeling groups (listed in Table 1 of this paper) for producing and making available their model output. For CMIP the U.S. Department of Energy's Program for Climate Model Diagnosis and Intercomparison provides coordinating support and led development of software infrastructure in partnership with the Global Organization for Earth System Science Portals. We are grateful to two anonymous reviewers, whose comments helped to substantially improve this manuscript.

\section{References}

Allison, E.A., 2015. The spiritual significance of glaciers in an age of climate change. WIREs Clim. Change 6 (5), 493-508.

Anderson, E.P., Marengo, J., Villalba, R., Halloy, S., Young, B., Cordero, D., Gast, F., Jaimes, E., Ruiz, D., 2011. Consequences of climate change for ecosystems and ecosystem services in the tropical Andes. In: Herzog, S.K., Martínez, R., Jørgensen, P.M., Tiessen, H. (Eds.), Climate Change and Biodiversity in the Tropical Andes. InterAmerican Institute for Global Change Research and Scientific Committee on Problems of the Environment, San Jose dos Campos and Paris.

Anthelme, F., Jacobsen, D., Macek, P., Meneses, R.I., Moret, P., Beck, S., Dangles, O., 2014. Biodiversity patterns and continental insularity in the high tropical Andes. Arct. Antarct. Alp. Res. 46, 811-830.

Baraer, M., Mark, B.G., McKenzie, J.M., Condom, T., Bury, J., Huh, K., Portocarrero, C., Gomez, J., Rathay, S., 2012. Glacier recession and water resources in Peru's Cordillera Blanca. J. Glaciol. 58 (207), 134-150.

Baraer, M., McKenzie, J., Mark, B.G., Gordon, R., Bury, J., Condom, T., Gomez, J., Knox, S., Fortner, S.K., 2015. Contribution of groundwater to the outflow from ungauged glazierized catchments: a multi-site study in the tropical Cordillera Blanca, Peru. Hydrol. Proc. 29 (11), 2561-2581.

Barberi, F., Martini, M., Rosi, M., 1990. Nevado del Ruiz volcano (Colombia): pre-eruption observations and the November 13, 1985 catastrophic event. J. Volcanol. Geotherm. Res. 42 (1), 1-12. http://dx.doi.org/10.1016/0377-0273(90)90066-O.

Barnett, T.P., Adam, J.C., Lettenmaier, D.P., 2005. Potential impacts of a warming climate on water availability in snow-dominated regions. Nature 438, 303-309.

Basantes-Serrano, R., Rabatel, A., Francou, B., Vincent, C., Maisincho, L., Caceres, B., Galarraga, R., Alvarez, D., 2016. Slight mass loss revealed by reanalyzing glacier mass-balance observations on Glaciar Antisana $15 \alpha$ (inner tropics) during the 1995-2012 period. J. Glaciol. 62 (231), 124-136. http://dx.doi.org/10.1017/jog. 2016.17.

Bebbington, A.J., Bury, J.T., 2009. Institutional challenges for mining and sustainability in Peru. Proc. Natl. Acad. Sci. 106, 17296.

Bebbington, A., Williams, M., 2008. Water and mining conflicts in Peru. Mt. Res. Dev. 28 (3/4), 190-195.

Benavides, J.C., Vitt, D.H., Wieder, R.K., 2013. The influence of climate change on recent peat accumulation patterns of Distichia muscoides cushion bogs in the high-elevation tropical Andes of Colombia. J. Geophys. Res. Biogeosci. 118 (4), 1627-1635.

Berthier, E., Cabot, V., Vincent, C., Six, D., 2016. Decadal region-wide and glacier-wide mass balances derived from multi-temporal ASTER satellite digital elevation models. Validation over the Mont-Blanc area. Front. Earth Sci. 4. http://dx.doi.org/10.3389/ feart.2016.

Blair, P., Buytaert, W., 2016. Socio-hydrological modeling: a review asking 'why, what and how?'. Hydrol. Earth Syst. Sci. 20, 443-478. http://dx.doi.org/10.5194/hess-20443-2016.

Boelens, R., 2014. Cultural politics and the hydrosocial cycle: water, power and identity in the Andean highlands. Geoforum 57, 234-247.

Bradley, R.S., Keimig, F.T., Diaz, H.F., 2004. Projected temperature change along the American cordillera and the planned GCOS network. Geophys. Res. Lett. 31, L16210. http://dx.doi.org/10.1029/2004GL020229.

Bradley, R.S., Vuille, M., Diaz, H.F., Vergara, W., 2006. Threats to water supplies in the tropical Andes. Science 312 (5781), 1755-1756.

Bradley, R.S., Keimig, F.T., Diaz, H.F., Hardy, D.R., 2009. Recent changes in freezing level heights in the tropics with implications for the deglacierization of high mountain regions. Geophys. Res. Lett. 36, L17701. http://dx.doi.org/10.1029/2009GL037712.

Braun, C., Bezada, M., 2013. The history and disappearance of glaciers in Venezuela. J. Lat. Am. Geogr. 12 (2), 85-124.

Brugger, J., Dunbar, K.W., Jurt, C., Orlove, B., 2013. Climates of anxiety: comparing experience of glacier retreat across three mountain regions. Emot. Space Soc. 6, 4-13.

Bury, J., 2008. New geographies of tourism in Peru: Nature-based tourism and conservation in the Cordillera Huayhuash. Tour. Geogr. 10 (3), 312-333.

Bury, J., 2015. The frozen frontier. The extractives super cycle in a time of glacier recession. In: Huggel, C., Carey, M., Clague, J., Kääb, A. (Eds.), The High-mountain Cryosphere. Cambridge University Press, Cambridge.

Bury, J.T., Mark, B.G., Mckenzie, J.M., French, A., Baraer, M., Huh, K.I., Zapata, M.A. Gomez, R.J., 2011. Glacier recession and human vulnerability in the Yanamarey watershed of the Cordillera Blanca, Peru. Clim. Chang. 105, 179-206.

Bury, J., Mark, B.G., Carey, M., Young, K., McKenzie, J., Baraer, M., French, A., Polk, M., 2013. New geographies of water and climate change in Peru: coupled natural and social transformations in the Santa River watershed. Ann. Am. Assoc. Geogr. 103 (2), 363-374.

Buytaert, W., Breuer, L., 2013. Water resources in South America: sources and supply, pollutants and perspectives. In: Understanding Freshwater Quality Problems in a Changing World. IAHS publications 359.

Buytaert, W., de Bievre, B., 2012. Water for cities: the impact of climate change and demographic growth in the tropical Andes. Water Resour. Res. 48, W08503. http:// dx.doi.org/10.1029/2011WR011755.

Buytaert, W., Celleri, R., De Bievre, B., Cisneros, F., Wyseure, G., Deckers, J., Hofstede, R, 2006. Human impact on the hydrology of the Andean paramos. Earth Sci. Rev. 79, $53-72$.

Buytaert, W., Iñiguez, V., De Bièvre, B., 2007. The effects of afforestation and cultivation on water yield in the Andean páramo. For. Ecol. Manage. 2511-2, 22-30.

Buytaert, W., Vuille, M., DeWulf, A., Urrutia, R., Karmalkar, A., Celleri, R., 2010. Uncertainties in climate change projections and regional downscaling in the tropical Andes: implications for water resources management. Hydrol. Earth Syst. Sci. 14, 1247-1258. 
Buytaert, W., Cuesta-Camacho, F., Tobon, C., 2011. Potential impacts of climate change on the environmental services of humid tropical alpine regions. Glob. Ecol. Biogeogr. 20, 19-33.

Buytaert, W., Zulkafli, Z., Grainger, S., Acosta, L., Alemie, T.C., Bastiaensen, J., De Bièvre, B., Bhusal, J., Clark, J., Dewulf, A., Foggin, M., Hannah, D.M., Hergarten, C., Isaeva, A., Karpouzoglou, T., Pandeya, B., Paudel, D., Sharma, K., Steenhuis, T.S., Tilahun, S., Van Hecken, G., Zhumanova, M., 2014. Citizen science in hydrology and water resources: opportunities for knowledge generation, ecosystem service management, and sustainable development. Front. Earth Sci. 2, 26.

Caballero, Y., Chevalier, P., Gallaire, R., Pillco, R., 2004. Flow modeling in a high mountain valley equipped with hydropower plants: Rio Zongo Valley, Cordillera Real Bolivia. Hydrol. Proc. 18 (5), 939-957.

Carey, M., 2010. In the Shadow of Melting Glaciers: Climate Change and Andean Society. Oxford University Press.

Carey, M., French, A., O'Brien, E., 2012a. Unintended effects of technology on climate change adaptation: an historical analysis of water conflicts below Andean glaciers. J. Hist. Geogr. 38, 181-191.

Carey, M., Huggel, C., Bury, J., Portocarrero, C., Haeberli, W., 2012b. An integrated socioenvironmental framework for glacier hazard management and climate change adaptation: lessons from Lake 513, Cordillera Blanca, Peru. Clim. Chang. 112, 733-767.

Carey, M., Baraer, M., Mark, B.G., French, A., Bury, J., Young, K.R., McKenzie, J.M., 2014 Toward hydro-social modeling: merging human variables and the social sciences with climate-glacier runoff models (Santa River, Peru). J. Hydrol. 518, 60-70.

Carey, M., Molden, O.C., Rasmussen, M.B., Jackson, M., Nolin, A.W., Mark, B.G., 2017. Impacts of glacier recession and declining meltwater on mountain societies. Ann. Am. Assoc. Geogr. 107 (2), 350-359.

Cauvy-Fraunié, S., Espinosa, R., Andino, P., Jacobsen, D., Dangles, O., 2015. Invertebrate metacommunity structure and dynamics in an Andean glacial stream network facing climate change. PLoS One 10 (8), e0136793.

Cauvy-Fraunié, S., Andino, P., Espinosa, R., Calvez, R., Jacobsen, D., Dangles, O., 2016. Ecological responses to experimental glacier-runoff reduction in alpine rivers. Nat. Commun. 7, 12025. http://dx.doi.org/10.1038/ncomms12025.

Chevallier, P., Pouyaud, B., Suarez, W., Condom, T., 2011. Climate change threats to environment in the tropical Andes: glaciers and water resources. Reg. Environ. Chang. 11, 179-187.

Colonia, D., Torres, J., Haeberli, W., Schauwecker, S., Braendle, E., Giraldez, C., Cochachin, A., 2017. Compiling an inventory of glacier-bed overdeepenings and potential new lakes in de-glaciating areas of the Peruvian Andes: approach, first results, and perspectives for adaptation to climate change. Water 9, 336. http://dx.doi. org/10.3390/w9050336.

Condom, T., Coudrain, A., Sicart, J.E., Thery, S., 2007. Computation of the space and time evolution of equilibrium-line altitudes on Andean glaciers $\left(10^{\circ} \mathrm{N}-55^{\circ} \mathrm{S}\right)$. Glob. Planet. Chang. 59, 189-202.

Condom, T., Escobar, M., Purkey, D., Pouget, J.C., Suarez, W., Ramos, C., Apaestegui, J., Tacsi, A., Gomez, J., 2012. Simulating the implications of glaciers' retreat for water management: a case study in the Rio Santa basin, Peru. Water Int. 37 (4), 442-459.

Cook, S.J., Kougkoulos, I., Edwards, L.A., Dortch, J., Hoffmann, D., 2016. Glacier change and glacial lake outburst flood risk in the Bolivian Andes. Cryosphere 10 (5), 2399-2413.

Córdova, M., Carrillo-Rojas, G., Crespo, P., Wilcox, B., Célleri, R., 2015. Evaluation of the Penman-Monteith (FAO 56PM) method for calculating reference evapotranspiration using limited data. Mt. Res. Dev. 35 (3), 230-239.

Cusicanqui, D., Soruco, A., Rabatel, A., Anthelme, F, 2015. Mass balance of Zongo glacie between 2006 and 2013 using volumetric method, employing Pléiades high resolution images acquired over the Cordillera Real, Bolivia $\left(16^{\circ} \mathrm{S}, 68^{\circ} \mathrm{W}\right)$. Rev. Boliv. Geosciencias 7, 5-20.

Dangles, O., Carpio, C., Barragan, A.R., Zeddam, J.-L., Silvain, J.-F., 2008. Temperature as a key driver of ecological sorting among invasive pest species in the tropical Andes. Ecol. Appl. 18, 1795-1809.

Dangles, O., Rabatel, A., Kraemer, M., Zeballos, G., Soruco, A., Jacobsen, D., Anthelme, F., 2017. Ecosystem sentinels for climate change? Evidence of wetland cover changes over the last 30 years in the high Bolivian Andes. PLoS One (in press).

Dee, D.P., Uppala, S.M., Simmons, A.J., Berrisford, P., Poli, P., Kobayashi, S., Andrae, U. Balmaseda, M.A., Balsamo, G., Bauer, P., Bechtold, P., Beljaars, A.C.M., van de Berg, L., Bidlot, J., Bormann, N., Delsol, C., Dragani, R., Fuentes, M., Geer, A.J., Haimberger, L., Healy, S.B., Hersbach, H., Hólm, E.V., Isaksen, L., Kållberg, P., Köhler, M., Matricardi, M., McNally, A.P., Monge-Sanz, B.M., Morcrette, J.-J., Park, B.-K., Peubey, C., de Rosnay, P., Tavolato, C., Thépaut, J.-N., Vitart, F., 2011. The ERA-Interim reanalysis: configuration and performance of the data assimilation system. Q. J. R. Meteorol. Soc. 137, 553-597.

Drenkhan, F., Carey, M., Huggel, C., Seidel, J., Ore, M.T., 2015. The changing water cycle: climatic and socio-economic drivers of water-related changes in the Andes of Peru. WIREs Water 2, 715-733.

Eichler, A., Gramlich, G., Kellerhals, T., Tobler, L., Schwikowski, M., 2015. Pb pollution from leaded gasoline in South America in the context of a 2000-year metallurgical history. Sci. Adv. 1 (2), e1400196. http://dx.doi.org/10.1126/sciadv.1400196.

Emmer, A., Vilímek, V., Klimes, J., Cochachin, A., 2014. Glacier retreat, lakes development and associated natural hazards in Cordillera Blanca, Peru. In: Shan, W., Guo, Y., Wang, F., Marui, H., Strom, A. (Eds.), Landslides in Cold Regions in the Context of Climate Change. Springer, New York, pp. 231-252.

Escurra, J.J., Vazquez, V., Cestti, R., De Nys, E., Srinivasan, R., 2014. Climate change impact on countrywide water balance in Bolivia. Reg. Environ. Chang. 14 (2), 727-742.

Evans, S.G., Bishop, N.F., Smoll, L.F., Murillo, P.V., Delaney, K.B., Oliver-Smith, A., 2009 A re-examination of the mechanism and human impact of catastrophic mass flows originating on Nevado Huascarán, Cordillera Blanca, Peru in 1962 and 1970. Eng. Geol. 108 (1-2), 96-118.

Farinotti, D., Brinkerhoff, D., Clarke, G.K.C., Fürst, J.J., Frey, H., Gantayat, P., GilletChaulet, F., Girard, C., Huss, M., Leclercq, P.W., Linsbauer, A., Machguth, H., Martin, C., Maussion, F., Morlighem, M., Mosbeux, C., Pandit, A., Portmann, A., Rabatel, A., Ramsankaran, R., Reerink, T.J., Sanchez, O., Stentoft, P.A., Singh Kumari, S., van Pelt, W.J.J., Anderson, B., Benham, T., Binder, D., Dowdeswell, J.A., Fischer, A., Helfricht, K., Kutuzov, S., McNabb, R., Gudmundsson, G.H., Li, H., Andreassen, L.M., 2017. How accurate are estimates of glacier ice thickness? Results from ITMIX, the Ice Thickness Models Intercomparison eXperiment. Cryosphere 11, 949-970.

Favier, V., Wagnon, P., Ribstein, P., 2004. Glaciers of the outer and inner tropics: a different behavior but a common response to climatic forcing. Geophys. Res. Lett. 31, L16403. http://dx.doi.org/10.1029/2004GL020654.

Favier, V., Coudrain, A., Cadier, E., Francou, B., Ayabaca, E., Maisincho, L., Praderio, E., Villacis, M., Wagnon, P., 2008. Evidence of groundwater flow on Antizana ice-covered volcano, Ecuador. Hydrol. Sci. J. 58 (1), 278-291.

Feeley, K.J., Silman, M.R., 2010. Land use and climate change effects on population size and extinction risk of Andean plants. Glob. Chang. Biol. 16 (12), 3215-3222.

Feeley, K.J., Silman, M.R., Bush, M.B., Farfan, W., Cabrera, K.G., Malhi, Y., Meir, P., Revillla, N.S., Quisiyupanqui, M.N.R., Saatchi, S., 2011. Upslope migration of Andean trees. J. Biogeogr. 38, 783-791.

Fernandez, A., Mark, B.G., 2016. Modeling modern glacier response to climate changes along the Andes Cordillera: A multiscale review. J. Adv. Model. Earth Syst. 8. http:// dx.doi.org/10.1002/2015MS000482.

Finer, M., Jenkins, C.N., 2012. Proliferation of hydroelectric dams in the Andean Amazon and implications for Andes-Amazon connectivity. PLoS One 7, e35126.

Flanner, M.G., Zender, C.S., Randerson, J.T., Rasch, P.J., 2007. Present-day climate forcing and response from black carbon in snow. J. Geophys. Res. Atmos. 112 (D11), D11202. http://dx.doi.org/10.1029/2006jd008003.

Fortner, S.K., Mark, B.G., McKenzie, J.M., Bury, J., Trierweiler, A., Baraer, M., Burns, P.J., Munk, L., 2011. Elevated stream trace and minor element concentrations in the foreland of receding tropical glaciers. Appl. Geochem. 26 (11), 1792-1801.

Francou, B., Vuille, M., Wagnon, P., Mendoza, J., Sicart, J.E., 2003. Tropical climate change recorded by a glacier in the central Andes during the last decades of the 20th century: Chacaltaya, Bolivia, $16^{\circ} \mathrm{S}$. J. Geophys. Res. 108 (D5), 4154. http://dx.doi. org/10.1029/2002JD002959.

Francou, B., Vuille, M., Favier, V., Cáceres, B., 2004. New evidence for an ENSO impact on low latitude glaciers: Antizana 15, Andes of Ecuador, $0^{\circ} 28^{\prime}$ S. J. Geophys. Res. 109 , D18106. http://dx.doi.org/10.1029/2003JD004484.

Frans, C., Istanbulluoglu, E., Lettenmaier, D.P., Naz, B., Clarke, G., Condom, T., Burns, P., Nolin, A., 2015. Predicting glacio-hydrologic change in the headwaters of the Zongo River, Cordillera Real, Bolivia. Water Resour. Res. 51. http://dx.doi.org/10.1002/ 2014WR016728.

Gagné, K., Rasmussen, M.B., Orlove, B., 2014. Glaciers and society: attributions, perceptions, and valuations. WIREs Clim. Change 5, 793-808.

Gardelle, J., Berthier, E., Arnaud, Y., Kaab, A., 2013. Region-wide glacier mass balances over the Pamir-Karakoram-Himalaya during 1999-2011. Cryosphere 7 (6), $1885-1886$.

Garreaud, R., Vuille, M., Clement, A., 2003. The climate of the Altiplano: observed current conditions and mechanisms of past changes. Palaeobot. Palynol. 194, 5-22.

Gilbert, A., Wagnon, P., Vincent, C., Ginot, P., Funk, M., 2010. Atmospheric warming at a high-elevation tropical site revealed by englacial temperatures at Illimani, Bolivia (6340 m above sea level, 16 S, 67 W). J. Geophys. Res. 115, 10109. http://dx.doi. org/10.1029/2009JD012961.

Ginot, P., Dumont, M., Lim, S., Patris, N., Taupin, J.D., Wagnon, P., Gilbert, A., Arnaud, Y., Marinoni, A., Bonasoni, P., Laj, P., 2014. A 10 year record of black carbon and dust from a Mera Peak ice core (Nepal): variability and potential impact on melting of Himalayan glaciers. Cryosphere 8 (4), 1479-1496.

Godon, C., Mugnier, J.-L., Fallourd, R., Paquette, J.-L., Pohl, A., Buoncristiani, J.F., 2013 The Bossons glacier protects Europe's summit from erosion. Earth Planet. Sci. Lett. 375, 135-147.

Gordon, R.P., Lautz, L.K., McKenzie, J.M., Mark, B.G., Chavez, D., Baraer, M., 2015 Sources and pathways of stream generation in tropical proglacial valleys of the Cordillera Blanca, Peru. J. Hydrol. 522, 628-644.

Gruber, S., Haeberli, W., 2007. Permafrost in steep bedrock slopes and its temperaturerelated destabilization following climate change. J. Geophys. Res. 112, F02S18. http://dx.doi.org/10.1029/2006JF000547.

Gurgiser, W., Moelg, T., Nicholson, L., Kaser, G., 2013. Mass-balance model parameter transferability on a tropical glacier. J. Glaciol. 59 (217), 845-858.

Haeberli, W., Buetler, M., Huggel, C., Friedli, T.L., Schaub, Y., Schleiss, A.J., 2016. New lakes in deglaciating high-mountain regions - opportunities and risks. Clim. Chang. 1-14. http://dx.doi.org/10.1007/s10584-016-1771-5.

Hallegatte, S., 2009. Strategies to adapt to an uncertain climate change. Glob. Environ. Chang. 19, 240-247.

Hanshaw, M.N., Bookhagen, B., 2014. Glacial areas, lake areas, and snow lines from 1975 to 2012: Status of the Cordillera Vilcanota, including the Quelccaya ice cap, northern central Andes, Peru. Cryosphere 8, 359-376.

Haylock, M.R., Peterson, T.C., Alves, L.M., Ambrizzi, T., Anunciacao, M.T., aBae, J., Barros, V.R., Berlato, M.A., Bidegain, M., Coronel, G., Corradi, V., Garcia, V.J., Grimm, A.M., Karoly, D., Marengo, J.A., Marino, M.B., Moncunill, D.F., Nechet, D., Quintana, J., Rebello, E., Rusticucci, M., Santos, J.L., Trebejo, I., Vincent, L.A., 2006. Trends in total and extreme South American rainfall in 1960-2000 and links with sea surface temperature. J. Clim. 19, 1490-1512.

Hegglin, E., Huggel, C., 2008. An integrated assessment of vulnerability to glacial hazards: a case study in the Cordillera Blanca, Peru. Mt. Res. Dev. 28 (3-4), 299-309. Hoffmann, D., 2012. Participatory glacier lake monitoring in Apolobamba protected area. 
A Bolivian experience. J. Sustain. Educ. http://www.jsedimensions.org/wordpress/ content/participatory-glacier-lake-monitoring-in-apolobamba-protected-area-abolivian-experience_2012_03/.

Hole, D.G., Young, K.R., Seimon, A., Wichtendahl, C.G., Hoffmann, D., Schutze Paez, K., Sanchez, S., Muchoney, D., Grau, H.R., Ramirez, E., 2011. Adaptive management for biodiversity conservation under climate change - a tropical Andean perspective. In Herzog, S.K., Martínez, R., Jørgensen, P.M., Tiessen, H. (Eds.), Climate Change and Biodiversity in the Tropical Andes. San Jose dos Campos and Paris: Inter-American Institute for Global Change Research and Scientific Committee on Problems of the Environment.

Huggel, C., Rohrer, M., Calanca, P., Salzmann, N., Vergara, W., Quispe, N., Ceballos, J.L, 2012. Early warning systems: The "last mile" of adaptation. Eos 93 (22), 209-210.

Huggel, C., Scheel, M., Albrecht, F., Andres, N., Calanca, P., Jurt, C., Khabarov, N., MiraSalama, D., Rohrer, M., Salzmann, N., Silva, Y., Silvestre, E., Vicuna, L., Zappa, M., 2015. A framework for the science contribution in climate adaptation: Experiences from the science-policy processes in the Andes. Environ. Sci. Pol. 47, 80-94.

Hurley, J.V., Vuille, M., Hardy, D.R., 2016. Forward modeling of $\delta^{18} \mathrm{O}$ in Andean ice cores. Geophys. Res. Lett. 43 (15), 8178-8188.

Huss, M., Bookhagen, B., Huggel, C., Jacobsen, D., Bradley, R.S., Clague, J.J., Vuille, M., Buytaert, W., Cayan, D.R., Greenwood, G., Mark, B.G., Milner, A.M., Weingartner, R., Winder, M., 2017. Toward mountains without permanent snow and ice. Earth Future 5. http://dx.doi.org/10.1002/2016EF000514.

Hylander, S., Jephson, T., Lebret, K., von Einem, J., Fagerberg, T., Balseiro, E., Modenutti, B., Sol, Souza B., Laspoumaderes, C., Jönsson, M., Ljungberg, P., Nicolle, A., Nilsson, P.A., Ranåker, L., Hansson, L.-A., 2011. Climate-induced input of turbid glacial meltwater affects vertical distribution and community composition of phyto- and zooplankton. J. Plankton Res. 33, 1239-1248.

Jacobsen, D., Milner, A.M., Brown, L.E., Dangles, O., 2012. Biodiversity under threat in glacier-fed river systems. Nat. Clim. Chang. 2, 361-364.

Jacobsen, D., Cauvy-Fraunié, S., Andino, P., Espinosa, R., Dangles, O., 2014. Variations in glacial runoff change longitudinal distribution patterns of macroinvertebrates in an Ecuadorian glacier-fed stream: implications for effects of global warming? Freshw. Biol. 59, 2038-2050.

Jansson, P., Hock, R., Schneider, T., 2003. The concept of glacier storage: a review. J. Hydrol. 282 (1), 116-129.

Jomelli, V., Favier, V., Rabatel, A., Brunstein, D., Hoffmann, G., Francou, B., 2009 Fluctuations of glaciers in the tropical Andes over the last millennium and palaeoclimatic implications: a review. Palaeobot. Palynol. 281, 269-282. http://dx.doi.org/ 10.1016/j.palaeo.2008.10.033.

Juen, I, Kaser, G., Georges, C, 2007. Modeling observed and future runoff from a glacierized tropical catchment (Cordillera Blanca, Peru). Glob. Planet. Chang. 59 (1-4), $37-48$.

Jurt, C., Burga, M.D., Vicuna, L., Huggel, C., Orlove, B., 2015. Local perceptions in climate change debates: insights from case studies in the Alps and the Andes. Clim. Chang. 133 (3), 511-523.

Kaenzig, R., Rebetez, M., Serquet, G., 2016. Climate change adaptation of the tourism sector in the Bolivian Andes. Tour. Geogr. 18 (2), 111-128.

Kalnay, E., Kanamitsu, M., Kistler, R., Collins, W., Deaven, D., Gandin, L., Iredell, M., Saha, S., White, G., Woollen, J., Zhu, Y., Leetmaa, A., Reynolds, R., Chelliah, M., Ebisuzaki, W., Higgins, W., Janowiak, J., Mo, K., Ropelewski, C., Wang, J., Jenne, R. Joseph, D., 1996. The NCEP/NCAR 40-year reanalysis project. Bull. Am. Meteorol. Soc. $77,437-471$.

Kaser, G., 1999. A review of the modern fluctuations of tropical glaciers. Glob. Planet. Change 22, 93-103.

Kaser, G., Osmaston, H.A., 2002. Tropical Glaciers. Cambridge University Press, New York (209 pp.).

Kaser, G., Grosshauser, M., Marzeion, B., 2010. Contribution potential of glaciers to water availability in different climate regimes. Proc. Natl. Acad. Sci. 107 (47), 20223-20227.

Kaspari, S.D., Schwikowski, M., Gysel, M., Flanner, M.G., Kang, S., Hou, S., Mayewski, P.A., 2011. Recent increase in black carbon concentrations from a Mt. Everest ice core spanning 1860-2000 AD. Geophys. Res. Lett. 38, L04703. http://dx.doi.org/10. 1029/2010GL046096.

LaFreniere, J., Mark, B.G., 2014. A review of methods for estimating the contribution of glacial meltwater to total watershed discharge. Prog. Phys. Geogr. 38 (2), 173-200.

Lasage, R., Muis, S., Sardella, C.S.E., van Drunen, M.A., Verburg, P.H., Aerts, J.C.J.H., 2015. A stepwise, participatory approach to design and implement community based adaptation to drought in the Peruvian Andes. Sustain. For. 7, 1742-1773. http://dx. doi.org/10.3390/su7021742.

Laspoumaderes, C., Modenutti, B., Sol, Souza M., Navarro, M.B., Cuassolo, F., Balseiro, E. 2013. Glacier melting and stoichiometric implications for lake community structure: zooplankton species distributions across a natural light gradient. Glob. Chang. Biol. $19,316-326$.

Lavado Casimiro, W.S., Labat, D., Ronchail, J., Espinoza, J.C., Guyot, J.L., 2013. Trends in rainfall and temperature in the Peruvian Amazon-Andes basin over the last 40 years (1965-2007). Hydrol. Proc. 41, 2944-2957.

Lejeune, Y., Wagnon, P., Bouilloud, L., Chevallier, P., Etchevers, P., Martin, E., Sicart, J.E., Habets, F., 2007. Melting of snow cover in a tropical mountain environment in Bolivia: processes and modeling. J. Hydrometeorol. 8, 922-937.

Loarte, E., Rabatel, A., Gomez, J., 2015. Determination of the spatio-temporal variation of the glacier equilibrium-line altitude from the snowline altitude in the Cordillera Blanca (Peru). Rev. Peru. Geo-Atmosferica 4, 19-30.

López-i-Gelats, F., Contreras Paco, J.L., Huilcas Huayra, R., Siguas Robles, O.D., Quispe Peña, E.C., Bartolomé Filella, J., 2015. Adaptation strategies of Andean pastoralist households to both climate and non-climate changes. Hum. Ecol. 43 (2), 267-282. Lopez-Moreno, J.J., Fontaneda, S., Bazo, J., Revuelto, J., Azorin-Molinia, C., Valero-
Garces, B., Moran-Tejeda, E., Vicente-Serrano, S.M., Zubieta, S.M., Alejo-Coachin, J., 2014. Recent glacier retreat and climate trends in Cordillera Huaytapallana, Peru. Glob. Planet. Chang. 112, 1-11.

Lopez-Moreno, J.I., Motran-Tejeda, E., Vicente-Serrano, S.M., Bazo, J., Azorin-Molina, C., Revuelto, J., Sanchez-Lorenzo, A., Navarro-Serrano, F., Aguilar, E., Chura, O., 2016. Recent temperature variability and change in the Altiplano of Bolivia and Peru. Int. J. Climatol. 36, 1773-1796. http://dx.doi.org/10.1002/joc.4459.

Loza Herrera, S., Meneses, R.I., Anthelme, F., 2015. Plant communities of high-Andean wetlands of the Cordillera Real (Bolivia) in the face of global warming. Ecología en Bolivia 50 (1), 39-56.

Lutz, D.A., Powell, R.L., Silman, M.R., 2013. Four decades of Andean timberline migration and implications for biodiversity loss with climate change. PLoS One 8 (9), e74496.

Lynch, B.D., 2012. Vulnerabilities, competition and rights in a context of climate change toward equitable water governance in Peru's Rio Santa Valley. Glob. Environ. Chang. $22(2), 364-373$.

Marengo, J.A., Espinoza, J.C., 2016. Extreme seasonal droughts and floods in Amazonia: causes, trends and impacts. Int. J. Climatol. 36, 1033-1050.

Mark, B.G., McKenzie, J.M., 2007. Tracing increasing tropical Andean glacier melt with stable isotopes in water. Environ. Sci. Technol. 41, 6955-6960.

Mark, B.G., Seltzer, G.O, 2003. Tropical glacier meltwater contribution to stream discharge: a case study in the Cordillera Blanca, Peru. J. Glaciol. 49 (165), 271-281.

Mark, B.G., Bury, J., McKenzie, J., French, A., Baraer, M., 2010. Climate change and tropical Andean glacier recession: Evaluating hydrologic changes and livelihood vulnerability in the Cordillera Blanca, Peru. Ann. Assoc. Am. Geogr. 100 (4), 794-805.

Maussion, F., Gurgiser, W., Grosshauser, M., Kaser, G., Marzeion, B., 2015. ENSO influence on surface energy and mass balance at Shallap glacier, Cordillera Blanca, Peru. Cryosphere 9, 1663-1683.

McColl, S.T., Davies, T.R.H., 2013. Large ice-contact slope movements: glacial debuttressing, deformation and erosion. Earth Surf. Process. Landf. 38, 1102-1115.

McDowell, J.Z., Hess, J.J., 2012. Accessing adaptation: multiple stressors on livelihoods in the Bolivian highlands under a changing climate. Glob. Environ. Chang. 22, 342-352.

Menon, S., Koch, D., Beig, G., Sahu, S., Fasullo, J., Orlikowski, D., 2010. Black carbon aerosols and the third polar ice cap. Atmos. Chem. Phys. 10 (10), 4559-4571. http:// dx.doi.org/10.5194/acp-10-4559-2010.

Mernild, S.H., Liston, G.E., Hiemstra, C.A., Malmros, J.K., Yde, J.C., McPhee, J., 2016. The Andes Cordillera. Part 1: snow distribution, properties and trends (1979-2014). Int. J. Climatol. http://dx.doi.org/10.1002/joc. 4804.

Michelutti, N., Wolfe, A.P., Cooke, C.C., Hobbs, W.O., Vuille, M., Smol, J.P., 2015. Climate change forces new ecological states in tropical Andean lakes. PLoS One 10 (2), e0115338.

Minvielle, M., Garreaud, R.D., 2011. Projecting rainfall changes over the South American Altiplano. J. Clim. 24, 4577-4583.

Molina, L.T., Gallardo, L., Andrade, M., Baumgardner, D., Borbor-Córdova, M., Bórquez, R., Casassa, G., Cereceda-Balic, F., Dawidowski, L., Garreaud, R., Huneeus, N., Lambert, F., McCarty, J.L., Mc Phee, J., Mena-Carrasco, M., Raga, G.B., Schmitt, C., Schwarz, J.P., 2015. Pollution and its impacts on the South American cryosphere. Earth Future 3. http://dx.doi.org/10.1002/2015EF000311.

Morera, S.B., Condom, T., Vauchel, P., Guyot, J.-L., Galvez, C., Crave, A., 2013. Pertinent spatio-temporal scale of observation to understand sediment yield control factors in the Andean Region: the case of the Santa River (Peru). Hydrol. Earth Syst. Sci. 17, $1-17$.

Morueta-Holme, N., Engemann, K., Sandoval-Acuna, P., Jonas, J.D., Segnitz, R.M., Svenning, J.C., 2015. Strong upslope shifts in Chimborazo's vegetation over two centuries since Humboldt. Proc. Natl. Acad. Sci. 112 (41), 12741-12745.

Moss, R.H., Edmonds, J.A., Hibbard, K.A., Manning, M.R., Rose, S.K., van Vuuren, D.P., Carter, T.R., Emori, S., Kainuma, M., Kram, T., Meehl, G.A., Mitchell, J.F.B., Nakicenovic, N., Riahi, K., Smith, S.J., Stouffer, R.J., Thomson, A.M., Weyant, J.P., Wilbanks, T.J., 2010. The next generation of scenarios for climate change research and assessment. Nature 463, 747-756.

Managing glacier related risks disaster in the Chucchún catchment, Cordillera Blanca, Peru. In: Muñoz, R., Gonzales, C., Price, K., Rosario, A., Huggel, C., Frey, H., García, J., Cochachín, A., Portocarrero, C., Mesa, L., Salzmann, N., Huggel, C., Nussbaumer Ziervogel, G. (Eds.), Climate Change Adaptation Strategies - Upstream - Downstream Perspectives. Springer, pp. 59-78. http://dx.doi.org/10.1007/978-3-319-40773-94.

Nakicenovic, N., Lempert, R.J., Janetos, A.C., 2014. A framework for the development of new socio-economic scenarios for climate change research: Introductory essay. Clim. Chang. 122 (3), 351-361. http://dx.doi.org/10.1007/s10584-013-0982-2.

Nazemi, A., Wheater, H.S., 2015. On inclusion of water resource management in Earth system models -Part 1: problem definition and representation of water demand. Hydrol. Earth Syst. Sci. 19 (1), 33-61.

Neukom, R., Rohrer, M., Calanca, P., Salzmann, N., Huggel, C., Acuna, D., Christie, D.A., Morales, M.S., 2015. Facing unprecedented drying of the Central Andes? Precipitation variability over the period 1000-2100. Environ. Res. Lett. 10, 084017.

Ochoa-Tocachi, B.F., Buytaert, W., De Bièvre, B., Célleri, R., Crespo, P., Villacís, M. Llerena, C.A., Acosta, L., Villazón, M., Guallpa, M., Gil-Ríos, J., Fuentes, P., Olaya, D., Viñas, P., Rojas, G., Arias, S., 2016. Impacts of land use on the hydrological response of tropical Andean catchments. Hydrol. Process. 30, 4074-4089.

Oliver-Smith, A., 1999. Peru's five-hundred-year earthquake: vulnerability in historical context. In: Oliver-Smith, A., Hoffman, S.M. (Eds.), The Angry Earth: Disaster in Anthropological Perspective. Routledge, New York, pp. 74-88.

O’Neill, B.C., Kriegler, E., Riahi, K., Ebi, K.L., Hallegatte, S., Carter, T.R., Mathur, R., van Vuuren, D.P., 2014. A new scenario framework for climate change research: the concept of shared socioeconomic pathways. Clim. Chang. 122 (3), 387-400. http:// 
dx.doi.org/10.1007/s10584-013-0905-2.

Oliver-Smith, A., Hoffman, S.M. (Eds.), 1999. The Angry Earth: Disaster in Anthropological Perspective. Routledge, New York.

Payne, L.B., Shepardon, D.P., 2015. Practitioners' views on useful knowledge for climate change adaptation projects. Sustain. Dev. 23, 355-368. http://dx.doi.org/10.1002/ sd.1596.

Pereira, G., Shimabukuro, Y.E., Moraes, E.C., Freitas, S.R., Cardozo, F.S., Longo, K.M., 2011. Monitoring the transport of biomass burning emission in South America. Atmos. Pollut. Res. 2 (3), 247-254. http://dx.doi.org/10.5094/apr.2011.031.

Pierson, T.C., Janda, R.J., Thouret, J.-C., Borrero, C.A., 1990. Perturbation and melting of snow and ice by the 13 November 1985 eruption of Nevado del Ruiz, Colombia, and consequent mobilization, flow and deposition of lahars. J. Volcanol. Geotherm. Res. 41 (1-4), 17-66. http://dx.doi.org/10.1016/0377-0273(90)90082-Q.

Pistolesi, M., Cioni, R., Rosi, M., Cashman, K.V., Rossotti, A., Aguilera, E., 2013. Evidence for lahar-triggering mechanisms in complex stratigraphic sequences: the post-twelfth century eruptive activity of Cotopaxi Volcano, Ecuador. Bull. Volcanol. 75 (3), 698 http://dx.doi.org/10.1007/s00445-013-0698-1.

Polk, M.H., Young, K.R., Baraer, M., Mark, B.G., McKenzie, J.M., Bury, J., Carey, M., 2017. Exploring hydrologic connections between tropical mountain wetlands and glacier recession in Peru's Cordillera Blanca. Appl. Geogr. 78, 94-103.

Postigo, J.C., 2014. Perception and resilience of Andean populations facing climate change. J. Ethnobiol. 34 (3), 383-400.

Postigo, J.C., Young, K.R., Crews, K.A., 2008. Change and continuity in a pastoralist community in the high Peruvian Andes. Hum. Ecol. 36 (4), 535-551.

Pouyaud, B., Zapata, M., Yerren, J., Gomez, J., Rosas, G., Suarez, W., Ribstein, P., 2005. On the future of the water resources from glacier melting in the Cordillera Blanca, Peru. Hydrol. Sci. J. 50, 999-1022.

Poveda, G., Pineda, K., 2009. Reassessment of Colombia's tropical glaciers retreat rates: are they bound to disappear during the 2010-2020 decade? Adv. Geosci. 22, 107-116.

Qiu, J., 2013. Pollutants capture the high ground in the Himalayas. Science 339, 1030-1031.

Quenta, E., Molina-Rodriguez, J., Gonzales, K., Rebaudo, F., Casas, J., Jacobsen, D., Dangles, O., 2016. Direct and indirect effects of glaciers on aquatic biodiversity in high Andean peatlands. Glob. Chang. Biol. 22 (9), 3196-3205.

Rabatel, A., Machaca, A., Francou, B., Jomelli, V., 2006. Glacier recession on Cerro Charquini $\left(16^{\circ} \mathrm{S}\right)$, Bolivia since the maximum of the Little Ice Age (17th century). J. Glaciol. 52 (176), 110-118.

Rabatel, A., Francou, B., Jomelli, V., Naveau, P., Grancher, D., 2008. A chronology of the Little Ice Age in the tropical Andes of Bolivia $\left(16^{\circ} \mathrm{S}\right)$ and its implications for climate reconstruction. Quat. Res. 70, 198-212.

Rabatel, A., Bermejo, A., Loarte, E., Soruco, A., Gomez, J., Leonardini, G., Vincent, C., Sicart, J.E., 2012. Can the snowline be used as an indicator of the equilibrium line and mass balance for glaciers in the outer tropics? J. Glaciol. 58 (212), 1027-1036.

Rabatel, A., Francou, B., Soruco, A., Gomez, J., Cáceres, B., Ceballos, J.L., Basantes, R., Vuille, M., Sicart, J.-E., Huggel, C., Scheel, M., Lejeune, Y., Arnaud, Y., Collet, M., Condom, T., Consoli, G., Favier, V., Jomelli, V., Galarraga, R., Ginot, P., Maisincho, L., Mendoza, J., Ménégoz, M., Ramirez, E., Ribstein, P., Suarez, W., Villacis, M., Wagnon, P., 2013. Current state of glaciers in the tropical Andes: a multi-century perspective on glacier evolution and climate change. Cryosphere 7, 81-102.

Rabatel, A., Dedieu, J.-P., Vincent, C., 2016. Spatio-temporal changes in glacier-wide mass balance quantified by optical remote-sensing on 30 glaciers in the French Alps for the period 1983-2014. J. Glaciol. 62 (236), 1153-1166. http://dx.doi.org/10. 1017/jog.2016.113.

Racoviteanu, A.E., Arnaud, Y., Williams, M.W., Ordonez, J., 2008. Decadal changes in glacier parameters in the Cordillera Blanca, Peru, derived from remote sensing. J. Glaciol. 34 (186), 499-510.

Ramanathan, V., Carmichael, G., 2008. Global and regional climate changes due to black carbon. Nat. Geosci. 1 (4), 221-227. http://dx.doi.org/10.1038/ngeo156.

Ramirez, E., Francou, B., Ribstein, P., Desclitres, M., Guerin, R., Mendoza, J., Gallaire, R., Pouyaud, B., Jordan, E., 2001. Small glaciers disappearing in the tropical Andes: a case study in Bolivia: Glaciar Chacaltaya (16 ${ }^{\circ}$ S). J. Glaciol. 47 (157), 187-194.

Rasmussen, M.B., 2016. Water futures: Contention in the construction of productive infrastructure in the Peruvian highland. Anthropologica. J. Can. Anthropol. Soc. 58 (2), 211-226.

Rau, P., Bourrel, L., Labat, D., Melo, P., Dewitte, B., Frappart, F., Lavado, W., Felipe, O. 2016. Regionalization of rainfall over the Peruvian Pacific slope and coast. Int. J. Climatol. http://dx.doi.org/10.1002/joc.4693.

Réveillet, M., Rabatel, A., Gillet-Chaulet, F., Soruco, A., 2015. Simulations of changes to Glacier Zongo, Bolivia (16S), over the 21st century using a 3-D full-Stokes model and CMIP5 climate projections. Ann. Glaciol. 56 (70), 89-97.

Rhoades, R., Zapata Rios, X., Aragundy Ochoa, J., 2008. Mama Cotacachi: history, local perceptions, and social impacts of climate change and glacier retreat in the Ecuadorian Andes. In: Orlove, B., Wiegandt, E., Luckman, B. (Eds.), Darkening Peaks. Glacier Retreat, Science, and Society. 2008. University of California Press, Berkeley, pp. 216-225.

Rodbell, D.T., Delman, E.M., Abbott, M.B., Besonen, M.T., Tapia, P.M., 2014. The heavy metal concentration of Lake Junin national reserve, Peru: an unintended consequence of the juxtaposition of hydroelectricity and mining. GSA Today 24 (8), 4-10.

Roman-Cuesta, R.M., Carmona-Moreno, C., Lizcano, G., New, M., Silman, M., Knoke, T., Malhi, Y., Oliveras, I., Asbjornsen, H., Vuille, M., 2014. Synchronous fire activity in the tropical high Andes: an indication of regional climate forcing. Glob. Chang. Biol. 20, 1929-1942.

Saavedra, F.A., Kampf, S.K., Fassnacht, S.R., Sibold, J.S., 2016. A snow climatology of the Andes Mountains from MODIS snow cover data. Int. J. Climatol. http://dx.doi.org/ 10.1002/joc. 4795 .
Sagredo, E.A., Rupper, S., Lowell, T.V., 2014. Sensitivities of the equilibrium line altitude to temperature and precipitation changes along the Andes. Quat. Res. 81 (2), 355-366.

Salzmann, N., Huggel, C., Calanca, P., Díaz, A., Jonas, T., Jurt, C., Konzelmann, T., Lagos, P., Rohrer, M., Silverio, W., Zappa, M., 2009. Integrated assessment and adaptation to climate change impacts in the Peruvian Andes. Adv. Geosci. 22, 35-39. http://dx.doi. org/10.5194/adgeo-22-35-2009.

Salzmann, N., Huggel, C., Rohrer, M., Silverio, W., Mark, B.G., Burns, P., Portocarrero, C., 2013. Glacier changes and climate trends derived from multiple sources in the data scarce Cordillera Vilcanota region, southern Peruvian Andes. Cryosphere 7, 103-118.

Salzmann, N., Huggel, C., Rohrer, M., Stoffel, M., 2014. Data and knowledge gaps in glacier, snow and related runoff research - a climate change adaptation perspective. J. Hydrol. 518, 225-234.

Schauwecker, S., Rohrer, M., Acuna, D., Coachin, A., Davila, L., Frey, H., Giraldez, C., Gomez, J., Huggel, C., Jacques-Coper, M., Loarte, E., Salzmann, N., Vuille, M., 2014. Climate trends and glacier retreat in the Cordillera Blanca, Peru, revisited. Glob. Planet. Chang. 119, 85-97.

Schauwecker, S., Rohrer, M., Huggel, C., Endries, J., Montoya, N., Neukom, R., Perry, B., Salzmann, N., Schwarb, M., Suarez, W., 2017. The freezing level in the tropical Andes, Peru: an indicator for present and future glacier extents. J. Geophys. Res. Atmos. 122. http://dx.doi.org/10.1002/2016JD025943.

Schmitt, C.G., All, J.D., Schwarz, J.P., Arnott, W.P., Cole, R.J., Lapham, E., Celestian, A., 2015. Measurements of light-absorbing particles on the glaciers in the Cordillera Blanca, Peru. Cryosphere 9, 331-340.

Schneider, D., Huggel, C., Cochachin, A., Guillen, S., Garcia, J., 2014. Mapping hazards from glacier lake outburst floods based on modeling of process cascades at Lake 513 Carhuaz, Peru. Adv. Geosci. 35, 145-155.

Schotterer, U., Grosjean, M., Stichler, W., Ginot, P., Kull, C., Bonnaveira, H., Francou, B., Gäggeler, H.W., Gallaire, R., Hoffmann, G., Pouyaud, B., Ramirez, E., Schwikowski, M., Taupin, J.D., 2003. Glaciers and climate in the Andes between the equator and $30^{\circ} \mathrm{S}$ : What is recorded under extreme environmental conditions? Clim. Chang. 59, 157. http://dx.doi.org/10.1023/A:1024423719288.

Seiler, C., Hutjes, R.W.A., Kabat, P., 2013a. Climate variability and trends in Bolivia. J. Appl. Meteorol. Climatol. 52, 1303-1317.

Seiler, C., Hutjes, R.W.A., Kabat, P., 2013b. Likely ranges of climate change in Bolivia. J. Appl. Meteorol. Climatol. 52, 130-146.

Seimon, T.A., Seimon, A., Daszak, P., Halloy, S.R.P., Schloegel, L.M., Aguliar, C.A., Sowell, P., Hyatt, A.D., Konecky, B., Simmons, J.E., 2007. Upward range extension of Andean anurans and chytridiomycosis to extreme elevations in response to tropical deglaciation. Glob. Chang. Biol. 13, 288-299.

Sicart, J.E., Arnaud, Y., 2007. Preliminary spectral characterization of snow in a high altitude tropical glacier and potential effects of impurities in snow on albedo of tropical glaciers. Hydrol. Proc. 21 (26), 3642-3644. http://dx.doi.org/10.1002/hyp. 6741.

Sicart, J.E., Wagnon, P., Ribstein, P., 2005. Atmospheric controls of the heat balance of Zongo Glacier (16 ${ }^{\circ}$ S, Bolivia). J. Geophys. Res. 110, D12106. http://dx.doi.org/10. 1029/2004JD005732.

Sicart, J.E., Hock, R., Ribstein, P., Chazarin, J.P., 2010. Sky longwave radiation on tropical Andean glaciers: parameterization and sensitivity to atmospheric variables. J. Glaciol. 56 (199), 854-860.

Sicart, J.E., Hock, R., Ribstein, P., Litt, M., Ramirez, E., 2011. Analysis of seasonal variations in mass balance and meltwater discharge of the tropical Zongo glacier by application of a distributed energy balance model. J. Geophys. Res. 116, D13105. http://dx.doi.org/10.1029/2010JD015105.

Sicart, J.E., Villacís, M., Condom, T., Rabatel, A., 2015. GREATICE monitors glaciers in the tropical Andes. Eos. http://dx.doi.org/10.1029/2015EO037993.

Sicart, J.E., Espinoza, J.C., Queno, L., Medina, M., 2016. Radiative properties of clouds over a tropical Bolivian glacier: seasonal variations and relationships with regional atmospheric circulation. Int. J. Climatol. 36 (8), 3116-3128. http://dx.doi.org/10. $1002 /$ joc. 4540

Sietz, D., Choque, S.E.M., Ludeke, M.K.B., 2012. Typical patterns of smallholder vulnerability to weather extremes with regard to food security in the Peruvian Altiplano. Reg. Environ. Chang. 12, 489-505.

Siraj, A.S., Santos-Vega, M., Bouma, M.J., Yadeta, D., Ruiz Carrascal, D., Pascual, M., 2014. Altitudinal changes in Malaria incidence in highlands of Ethiopia and Colombia. Science 343, 1154-1158.

Skarbø, K., VanderMolen, K., 2014. Irrigation access and vulnerability to climate-induced hydrological change in the Ecuadorian Andes. Cult. Agric. Food Environ. 36 (1), 28-44.

Solomina, O., Jomelli, V., Kaser, G., Ames, A., Berger, B., Pouyaud, B., 2007 Lichenometry in the Cordillera Blanca, Peru: "Little Ice Age" moraine chronology. Glob. Planet. Change 59, 225-235.

Somers, L.D., Gordon, R.P., McKenzie, J.M., Lautz, L.K., Wigmore, O., Glose, A.M., Glas, R., Aubry-Wake, C., Mark, B., Baraer, M., Condom, T., 2016. Quantifying groundwater-surface water interactions in a proglacial valley, Cordillera Blanca, Peru. Hydrol. Proc. http://dx.doi.org/10.1002/hyp.10912.

Somos-Valenzuela, M.A., Chisolm, R.E., Rivas, D.S., Portocarrero, C., McKinney, D.C., 2016. Modeling a glacial lake outburst flood process chain: the case of Lake Palcacocha and Huaraz, Peru. Hydrol. Earth Syst. Sci. 20, 2519-2543.

Soruco, A., Vincent, C., Francou, B., Gonzalez, J.F., 2009. Glacier decline between 1963 and 2006 in the Cordillera Real, Bolivia. Geophys. Res. Lett. 36, L03502. http://dx. doi.org/10.1029/2008GL036238.

Soruco, A., Vincent, C., Rabatel, A., Francou, B., Thibert, E., Sicart, J.E., Condom, T., 2015. Contribution of glacier runoff to water resources of La Paz city, Bolivia $\left(16^{\circ} \mathrm{S}\right)$. Ann. Glaciol. 56 (70), 147-154. http://dx.doi.org/10.3189/2015AoG70A001.

Squeo, F., Warner, B., Aravena, R., Espinoza, D., 2006. Bofedales: high altitude peatlands 
of the central Andes. Rev. Chil. Hist. Nat. 79, 245-255.

Thibeault, J.M., Seth, A., Garcia, M., 2010. Changing climate in the Bolivian Altiplano: CMIP3 projections for temperature and precipitation extremes. J. Geophys. Res. 115, D08103.

Thibeault, J.M., Seth, A., Wang, G., 2012. Mechanisms of summertime precipitation variability in the Bolivian Altiplano: present and future. Int. J. Climatol. 32, 2033-2041.

Tovar, C., Arnillas, C.A., Cuesta, F., Buytaert, W., 2013. Diverging responses of tropical Andean biomes under future climate conditions. PLoS One 8 (5), e63634.

Uglietti, C., Gabrielli, P., Cooke, C.A., Vallelonga, P., Thompson, L.G., 2015. Widespread pollution of the South American atmosphere predates the industrial revolution by 240 y. Proc. Natl. Acad. Sci. 112 (8), 2349-2354. http://dx.doi.org/10.1073/pnas. 1421119112.

Urrutia, R., Vuille, M., 2009. Climate change projections for the tropical Andes using a regional climate model: temperature and precipitation simulations for the end of the 21st century. J. Geophys. Res. 114, D02108. http://dx.doi.org/10.1029/ 2008JD011021.

Valdivia, C., Seth, A., Gilles, J.L., Garcia, M., Jimenez, E., Cusicanqui, J., Navia, F., Yucra, E., 2010. Adapting to climate change in Andean ecosystems: landscapes, capitals, and perceptions shaping rural livelihood strategies and linking knowledge systems. Ann. Assoc. Am. Geogr. 100, 818-834.

Veettil, B.K., Bayer Maier, E.L., Bremer, U.F., de Souza, S.F., 2014. Combined influence of PDO and ENSO on northern Andean glaciers: a case study on the Cotopaxi ice-covered volcano, Ecuador. Clim. Dyn. 43 (12), 3439-3448.

Vergara, W., Deeb, A.M., Valencia, A.M., Bradley, R.S., Francou, B., Zarzar, A. Gruenwaldt, A., Haeussling, S.M., 2007. Economic impacts of rapid glacier retreat in the Andes. Eos 88, 261-264.

Vilímek, V., Zapata Luyo, M., Klimeš, J., Zdenek, P., Santillán, N., 2005. Influence of glacial retreat on natural hazards of the Palcacocha Lake area, Peru. Landslides 2 , $107-115$.

Vimeux, F., Ginot, P., Schwikowski, M., Vuille, M., Hoffmann, G., Thompson, L.G., Schotterer, U., 2009. Climate variability during the last 1000 years inferred from Andean ice cores: a review of methodology and recent results. Palaeobot. Palynol. 281, 229-241. http://dx.doi.org/10.1016/j.palaeo.2008.03.054.

Viviroli, D., Archer, D., Buytaert, W., Fowler, H.J., Greenwood, G.B., Hamlet, A.F., Huang, Y., Koboltschnig, G., Litaor, M.I., Lopez-Moreno, J.I., Lorentz, S., Schaedler, B., Schreier, H., Schwaiger, K., Vuille, M., Woods, R., 2011. Climate change and mountain water resources: overview and recommendations for research, management and policy. Hydrol. Earth Syst. Sci. 15, 471-504.

Vuille, M., 2013. Climate Change and Water Resources in the Tropical Andes. Interamerican Development Bank Technical Note No. IDB-TN-515.

Vuille, M., Ammann, C., 1997. Regional snowfall patterns in the high arid Andes. Clim. Chang. 36 (3-4), 413-423.
Vuille, M., Bradley, R.S., 2000. Mean annual temperature trends and their vertical structure in the tropical Andes. Geophys. Res. Lett. 27, 3885-3888.

Vuille, M., Bradley, R.S., Werner, M., Keimig, F., 2003. 20th century climate change in the tropical Andes: observations and model results. Clim. Chang. 59 (1-2), 75-99.

Vuille, M., Francou, B., Wagnon, P., Juen, I., Kaser, G., Mark, B.G., Bradley, R.S., 2008a. Climate change and tropical Andean glaciers - past, present and future. Earth Sci. Rev. 89, 79-96. http://dx.doi.org/10.1016/j.earscirev.2008.04.002.

Vuille, M., Kaser, G., Juen, I., 2008b. Glacier mass balance variability in the Cordillera Blanca, Peru and its relationship with climate and the large-scale circulation. Glob. Planet. Chang. 62 (1-2), 14-28. http://dx.doi.org/10.1016/j.gloplacha.2007.11.003.

Vuille, M., Franquist, E., Garreaud, R., Lavado, W., Caceres, B., 2015. Impact of the global warming hiatus on Andean temperature. J. Geophys. Res. 120 (9), 3745-3757. http://dx.doi.org/10.1002/2015JD023126.

Wagnon, P., Ribstein, P., Kaser, G., Berton, P., 1999. Energy balance and runoff seasonality of a Bolivian glacier. Glob. Planet. Chang. 22, 49-58.

Wagnon, P., Ribstein, P., Francou, B., Sicart, J.E., 2001. Anomalous heat and mass budget of Glaciar Zongo, Bolivia, during the 1997-98 El Niño year. J. Glaciol. 47, 21-28.

Wagnon, P., Sicart, J.-E., Berthier, E., Chazarin, J.-P., 2003. Wintertime high-altitude surface energy balance of a Bolivian glacier, Illimani, $6340 \mathrm{~m}$ above sea level. J. Geophys. Res. 108 (6). http://dx.doi.org/10.1029/2002JD002088.

Wagnon, P., Lafaysse, M., Lejeune, Y., Misincho, L., Rojas, M., Chazarin, J.P., 2009. Understanding and modeling the physical processes that govern the melting of snow cover in a tropical mountain environment in Ecuador. J. Geophys. Res. 114, D19113.

Wilby, R.L., Dessai, S., 2010. Robust adaptation to climate change. Weather 65, 180-185. http://dx.doi.org/10.1002/wea.543.

Winkler, M., Juen, I., Moelg, T., Wagnon, P., Gomez, J., Kaser, G., 2009. Measured and modeled sublimation on the tropical Glaciar Artesonraju, Peru. Cryosphere 3, 21-30.

Xu, B., Cao, J., Hansen, J., Yao, T., Joswiak, D.R., Wang, N., Wu, G., Wang, M., Zhao, H., Yang, W., Liu, X., He, J., 2009. Black soot and the survival of Tibetan glaciers. Proc. Natl. Acad. Sci. 106 (52), 22114-22118.

Young, K., 2008. Stasis and Flux in Long-inhabited Locales: Change in Rural Andean Landscapes. Land Change Science in the Tropics. Springer, US, pp. 11-32.

Young, K.R., Lipton, J.K., 2006. Adaptive governance and climate change in the tropical highlands of western South America. Clim. Chang. 78, 63-102.

Zimmer, A., Meneses, R.I., Rabatel, A., Soruco, A., Dangles, O., Anthelme, F., 2017. Time lag between glacial retreat and upward migration alters tropical alpine communities. Perspect. Plant Ecol. Evol. Syst. http://dx.doi.org/10.1016/j.ppees.2017.05.003. (in press).

Zulkafli, Z., Buytaert, W., Manz, B., Rosas, C.V., Willems, P., Lavado-Casimiro, W., Guyot, J.-L., Santini, W., 2016. Projected increases in the annual flood pulse of the Western Amazon. Environ. Res. Lett. 11 (1), 014013. http://dx.doi.org/10.1088/1748-9326/ 11/1/014013. 